\title{
Recent investigations into synthesis and pharmacological activities of phenoxy acetamide and its derivatives (chalcone, indole and quinoline) as possible therapeutic candidates
}

\author{
Fares Hezam Al-Ostoot ${ }^{1,2} \cdot$ Zabiulla $^{3} \cdot$ Salma Salah $^{4} \cdot$ Shaukath Ara Khanum $^{1}$
}

Received: 24 November 2020 / Accepted: 2 January 2021 / Published online: 1 February 2021

(c) Iranian Chemical Society 2021

\begin{abstract}
Medicinal chemistry can rightfully be regarded as a cornerstone in the public health of our modern society that combines chemistry and pharmacology with the aim of designing and developing new pharmaceutical compounds. For this purpose, many chemical techniques as well as new computational chemistry applications are used to study the utilization of drugs and their biological effects. In the biological interface, medicinal chemistry constitutes a group of interdisciplinary sciences, as well as controlling its organic, physical and computational pillars. Therefore, medicinal chemists working to design an integrated and developing system that portends an era of novel and safe tailored drugs either by synthesizing new pharmaceuticals or to improving the processes by which existing pharmaceuticals are made. It includes researching the effects of synthetic, semi-synthetic and natural biologically active substances based on molecular interactions in terms of molecular structure with triggered functional groups or the specific physicochemical properties. The present work focuses on the literature survey of chemical diversity of phenoxy acetamide and its derivatives (Chalcone, Indole and Quinoline) in the molecular framework in order to get complete information regarding pharmacologically interesting compounds of widely different composition. From a biological and industrial point of view, this literature review may provide an opportunity for the chemists to design new derivatives of phenoxy acetamide and its derivatives that proved to be the successful agent in view of safety and efficacy to enhance life quality.
\end{abstract}

Shaukath Ara Khanum

shaukathara@yahoo.co.in

1 Department of Chemistry, Yuvaraja's College, University of Mysore, Mysuru 570 006, India

2 Department of Biochemistry, Faculty of Education and Science, Al-Baydha University, Al-Baydha, Yemen

3 PG Department of Studies and Research Centre in Chemistry (A Recognized Research Centre of University of Mysore), St. Philomena's College Bannimantap, Mysuru, Karnataka, India

4 Faculty of Medicine and Health Sciences, Thamar University, Dhamar, Yemen 


\section{Graphical abstract}

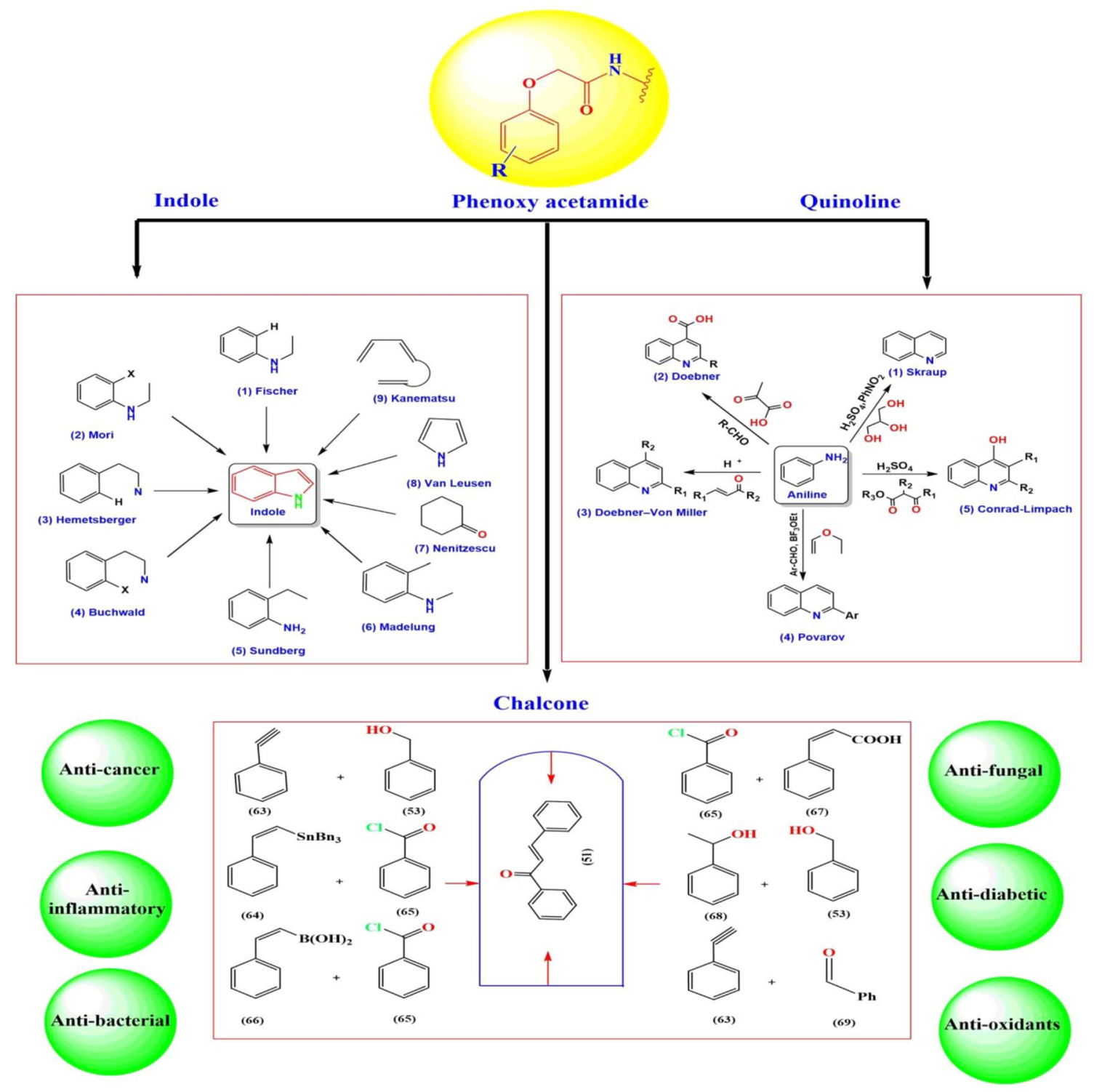

Keywords Medicinal chemistry $\cdot$ Phenoxy acetamide $\cdot$ Chalcone $\cdot$ Indole $\cdot$ Quinolone

\section{Abbreviations}

HPLC High-performance liquid chromatography

GCMS Gas chromatography-mass spectrometry

NMR Nuclear magnetic resonance spectroscopy

FTIR Fourier-transform infrared spectroscopy

TLC Thin-layer chromatography

LC/MS Liquid chromatography-mass spectrometry

X-ray

DCM

TBTU

IC50
$\mathrm{X}$-radiation

Dichloromethane

2-(1H-benzotriazole-1-yl)-1,1,3,3-tetramethylaminium tetrafluoroborate

Half-maximal inhibitory concentration
MTT

$\mathrm{T}_{3} \mathrm{P} \quad$ Propylphosphonic anhydride

5-FU 5-Fluorouracil

HIF-1 $\alpha$ Hypoxia-inducible factor 1-alpha

MDM-2 Mouse doubles minute 2

AChE Acetylcholinesterase

BChE Butyrylcholinesterase

CTX Chemotherapy

H37Rv Mycobacterium tuberculosis strain

DPPH 2,2-Diphenyl-1-picrylhydrazyl

NO Nitric oxide 


$\begin{array}{ll}\text { CDI } & \text { Carbonyldiimidazole } \\ \text { DMAP } & \text { 4-Dimethyl aminopyridine } \\ \text { COX-2 } & \text { Cyclooxygenase 2 } \\ \text { VEGFr-2 } & \text { Vascular endothelial growth factor receptors-2 } \\ \text { SF268 } & \text { Human glioblastoma cell line } \\ \text { HCT-15 } & \text { Human colon cancer cell line } \\ \text { HCT-116 } & \text { Human colorectal carcinoma cell line } \\ \text { MCF-7 } & \text { Human breast cancer cell line } \\ \text { PC-3 } & \text { Human prostate cancer cell line } \\ \text { SF539 } & \text { Human brain cancer cell line } \\ \text { HepG-2 } & \text { Human liver cancer cell line }\end{array}$

\section{An overview of medicinal chemistry using chemotherapy: an introduction}

Medicinal chemistry can rightfully be regarded as a cornerstone in the public health of our modern society [1]. It is one of the chemistry branches that intersect with pharmaceutical chemistry, especially in industrial organic chemistry, pharmacology and other biological disciplines, which deals with the composition of pharmaceutical substances or biologically active drugs, and their chemical synthesis [2]. Medicinal chemistry is a scientific discipline that combines chemistry and pharmacology with the aim of designing and developing new pharmaceutical compounds or more correctly, it combines pharmacology and organic chemistry [3]. Therefore, medicinal chemistry can identify, manufacture and develop new chemical compounds for therapeutic uses: increasing their therapeutic effect and decreasing side effects to maintain and improve the health of the human being [4]. Furthermore, medicinal chemistry plays one of the most important roles in modern healthcare because of its effective role in preserving human life by providing a lot of medicinal drugs and medical preparations [5]. For this purpose, many chemical and technical techniques as well as new computational chemistry applications are used to study the utilization of drugs and their biological effects [6]. In the biological interface, medicinal chemistry constitutes a group of interdisciplinary sciences, as well as controlling its organic, physical and computational pillars [7]. Medicinal practitioners have a strong background in organic chemistry as well as an understanding of biological principles related to cellular pharmacological drug targeting and to use of chemical principles to design effective therapeutic drugs [8].

The discovery of medicines has a long history which dates back to the early days of human civilization, even though the diseases were treated as enigmatic, mystical and frightens [9]. Within those ancient days, medicines were used not only for medical treatment but also for religious and incorporeal recovery [10]. Where the people were concerned about treating the mysterious diseases by using eating and drinking, as well as using specific plants and herbs, and experimenting randomly on patients [11]. This is due to ignorance of the nature and characteristics of the diseases at the time. Many archaic populations have recorded the therapeutic characteristic of individual selected plants and elixirs resulting from the required testing and error study for cures for specific conditions [12].

Essential medicines are now identified as some of those which fulfill the population's priority healthcare needs and are recommended in terms of disease prevalence and importance to public health, therapeutic effect and safety proof, as well as the impact of service quality [13]. Therefore, medicinal chemists working to design an integrated and developing system that portends an era of novel and safe tailored drugs either by synthesizing new pharmaceuticals or to improving the processes by which existing pharmaceuticals are made [14]. It includes researching the effects of synthetic, semisynthetic and natural biologically active substances based on molecular interactions in terms of molecular structure with triggered functional groups or the specific physicochemical properties [15]. Therefore, the contribution of medicinal chemistry to both the medicinal and pharmaceutical fields is significant, along with the production of medicines, detection, design and identification of biological activity [16].

\section{Modern process for drug discovery and development}

The task of seeking a new drug and developing is a complicated, challenging and costly process [17]. It specifically aims to find effective drugs with distinct consumer characteristics that can support humanity by relieving symptoms of the disease and prolonging its existence. The method of modern drug discovery has been revolutionized by successful technologies such as virtual screening, in-silico screening, structure-based drug design, de novo design, in-vitro as well as the advent of genomics, proteomics and bioinformatics [18-21].

\section{Development of chemistry processes}

After the design, the final stages of synthetic chemistry include the development of a lead compound in the required quantity and quality to support large-scale animal experiments and afterwards human clinical trials [22]. This includes refining the synthetic pathway for large industrial production and finding the most effective drug formulation [23]. Synthetic chemistry aimed at adapting and improving the synthetic route in medicinal chemistry and involves thorough knowledge of appropriate synthetic procedure in the sense of large-scale reactions including reaction thermodynamics, economics and safety [24]. 


\section{Structural analysis}

Structural analysis of the active compounds is often performed through computational methods prior to the actual synthesis of the ligands for several considerations, including time and financial considerations [25]. Pharmaceutical product structures are tested in several ways, primarily as a means of evaluating the effectiveness, safety and accessibility [26]. The five parameters of the Lipinski rule based on are the number of donors and acceptors of hydrogen bonds, a number of rotatable bonds, surface area and lipophilicity [27]. The synthetic complexity, chirality, flatness and aromatic ring count are other parameters whereby the medicinal chemists determine or classify their molecules [28]. Once the molecule of interest has been synthesized, different analysis methods such as TLC, NMR, GC/MS, LC/MS, HPLC/ MS/MS, GCMS, FTIR, X-ray, (electron and neutron diffraction), elemental analysis, microwave spectroscopy etc. are then performed [29].

\section{Chemotherapy trials}

Chemotherapy (CTX or CTx) is an aggressive form of chemical substance intended to kill quickly growth and evolving cells in the body [30]. Chemotherapy, also referred to as "chemical cure," has existed since the times of the ancient Greeks, but chemotherapy to treat cancer with the use of nitrogen mustard started mostly in the 1940s [31, 32]. Where used chemotherapy to cure cancer started with many attempts to establish new methods for evaluating the chemical effect in rodents by using transplantable different tumors [33]. Nowadays, this is also referred to as anti-tumor or anti-neoplastic drugs that may be administered for a curative purpose or it may be directed at minimizing symptoms (palliative chemotherapy) [34]. Chemotherapy can be seen to a huge extent as a means of destroying or disrupting cancer cells, which can then result in the death of cells (apoptosis) [35]. Notably, any use of medications represents a systemic cancer treatment in that they are delivered into the bloodstream and are thus able to resolve cancer at any anatomical place in the body [36]. Therefore, systemic therapy is most often used in combination with several other local cancer treatment methods, such as radiation therapy, surgery or hyperthermia therapy [37]. The aim of chemotherapy is always to prevent or delay the growth of cancer cells by reducing the total number of body cancer cells, minimize the possibility of cancer spreading, decreasing the size of the tumor and reducing current symptoms [38]. While chemotherapy is an effective treatment option for several types of cancer, but it sometimes poses a risk of side effects [39].

\section{An overview of phenoxy derivatives as possible therapeutic candidates}

Phenoxy acetic acid is an organic compound that represents a group of phenoxy acetic acid derivatives containing anisole in which acetic acid or its derivatives are linked to the methane group Fig. 1 [40]. Phenoxy acetic acid is often known to be monocarboxylic acid, which is the glycolic acid $O$-phenyl derivative with a sweet and sour tasting with significant smells like honey and can be found in cocoa and its products. Phenoxy acetic acid exists as solid crystals that have needle-shaped, colourless, readily soluble in ether, glacial acetic acid, as well as in ethanol solvent with medium-strong acid ( $\mathrm{pKs}=3.17)$. Further, it is used throughout the manufacture of pharmaceuticals, pesticides, fungicides and dyes [41-44]. Phenoxy acids and their derivatives are associated with a variety of biological activities such as herbicidal activity [45], anti-mycobacterial agents [46], anti-inflammatory activity [47], anti-leishmanial [48] and anti-viral activity [49].

\section{Introduction to the synthesis of phenoxy acid and its derivatives}

Interestingly, phenoxy acetic acid can be easily prepared by starting with phenol (1) and chloroacetic acid (3) with a solution of sodium hydroxide. The sodium hydroxide solution deprotonates the phenol hydroxy group. Finally, the resulting phenolate (2), now attacks the $a$-carbon atom of the chloroacetic acid nucleophilically, splitting off a chloride ion and then forming of phenoxy acetic acid compound (4), Scheme 1 [50].

Alternatively, our research group (Shaukath et al. 2008) has synthesized a series of phenoxy oxazolines (7) beginning
Fig. 1 i General structure of phenoxy acid, ii phenoxy acid derivatives
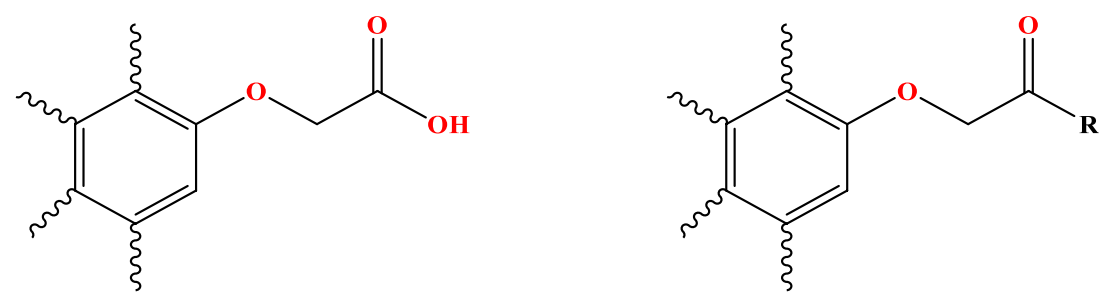
Scheme 1 Synthesis of phenoxy acetic acid<smiles>O=C(O)COc1ccc([O-])c(Cl)c1</smiles>

(2)

(3)<smiles>Brc1ccc(OCC2=NCCO2)cc1</smiles>

(6)<smiles>CC(C)(CN)OCC(=O)OCC(=O)O</smiles>

(4)
Scheme 2 Synthesis of phenoxy oxazoline<smiles>Oc1ccc(Br)cc1</smiles>

(5) with substituted phenols (5) and chloro acetic acid in the presence of acetone and anhydrous potassium carbonate to afford substituted phenoxy acetic acids (6). Finally phenoxy acetic acids and ethanolamine was subjected to microwave irradiation to have substituted phenoxy oxazolines. Among this series, good yield and potent activity was exhibited by para bromo phenoxy oxazoline as shown in Scheme 2 [51].

Also, in the year 2018, our research group has been synthesized a novel phenoxy thiazole derivative (13) starting from 2, 4-difluorophenol (8) and ethyl chloroacetate (9) in the presence of anhydrous potassium carbonate to achieve phenoxy ester (10). On hydrolysis, compound (10) converted to corresponding phenoxy acid (11) and finally this on coupling with 2-amino-4-(4-bromophenyl)thiazole (12) in the presence of dry dichloromethane (DCM), lutidine and 2-(1H-benzotriazole-1-yl)-1,1,3,3-tetramethylaminium tetrafluoroborate (TBTU) furnished compound (13) as shown in Scheme 3 [52].

\section{Pharmaceutical aspects of phenoxy derivatives}

\section{Phenoxy derivatives as anti-cancer agents}

In the year of 2018, a novel series of phenoxy thiazoles were synthesized by our research group and screened for cytotoxic and anti-proliferative activity against multiple cancer cells. The result revealed that compound (13) with methyl and fluoro substitute has potential cytotoxic efficacy with an average $\mathrm{IC}_{50}$ value of $13 \mu \mathrm{M}$. The potent compound (13) was further assessed for anti-tumor studies that showed significant role against the tumor cells by repressing HIF- $1 \alpha$ by p53/MDM-2 mediated degradation [52].

Other series derivatives were also investigated for their neoplastic development targeting matrix metalloproteases and tumor hypoxia activities. The experimental result favoured compound (14) with good cytotoxic efficacy with prolonged activity against different cancer cell lines as well as against Dalton's solid lymphoma progression [53]. 
<smiles>Oc1ccc(F)cc1F</smiles>

(8)

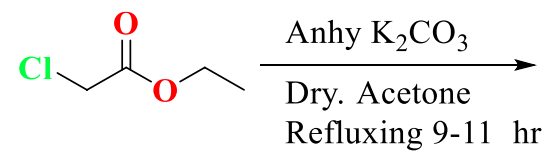

(9)<smiles>[R]CC(C)(C)ON</smiles>

(10)<smiles>O=C(O)COc1ccc(F)cc1F</smiles>

(11)<smiles>Cc1ccc(-c2csc(NC(=O)COc3ccc(F)cc3F)n2)cc1</smiles>

(13) $\frac{\text { DCM,TBTU,lutidine }}{0-5^{\circ} \mathrm{C} \text {, overnight }}$<smiles>Cc1ccc(-c2csc(N)n2)cc1</smiles>

(12)

Scheme 3 Synthesis of phenoxy thiazole<smiles>Cc1ccc(-c2csc(NC(=O)COc3ccc(F)cc3F)n2)cc1</smiles>

(13)

\section{Phenoxy derivatives as anti-nociceptive and anti-inflammatory agents}<smiles>CC(C)c1ccc(OCC(=O)NNc2ccc(Cl)nn2)c(C(C)C)c1</smiles>

(14)

A series of novel phenoxy acid hydrazides (15) were prepared by Turan et al. [54] and then evaluated for their antinociceptive and anti-inflammatory activities. Almost all of the derivatives were reported to demonstrate a nociceptive peripheral impact. The findings showed that the presence of acidic moiety enhanced the peripheral action of anti-nociception and decreased the central activity of anti-nociception. 
<smiles>[R][C-](C)O[N+](C)([O-])O[Na]</smiles>

A novel series of 2-(substituted phenoxy)- $N$-(1-phenylethyl) acetamide analogs (16) were synthesized by Priyanka et al. [55] using 1-phenylethylamine and substituted phenols. For their anti-inflammatory activity and analgesic activity, the synthesized phenoxy compounds were examined and the results indicated that halogen-containing phenoxy derivatives enhanced the anti-inflammatory function, while healthy anti-cancer, anti-inflammatory and analgesic activities have been seen in the derivatives carrying nitro group.

\section{Phenoxy derivatives as acetylcholinesterase inhibitors for Alzheimer's disease}

A novel series of 2-phenoxy-indan-1-ones (17) have been designed and synthesized by Rong Sheng et al. [56]. The phenoxy derivatives then subjected to in-vitro evaluation according to the modified Ellman method using rat cortex homogenate acetylcholinesterase (AChE) and rat serum butyrylcholinesterase (BChE) as acetylcholinesterase inhibitors. The result displayed that most of the compounds exhibited high activity of AChE inhibition, while all the compounds were almost inactive against $\mathrm{BChE}$.

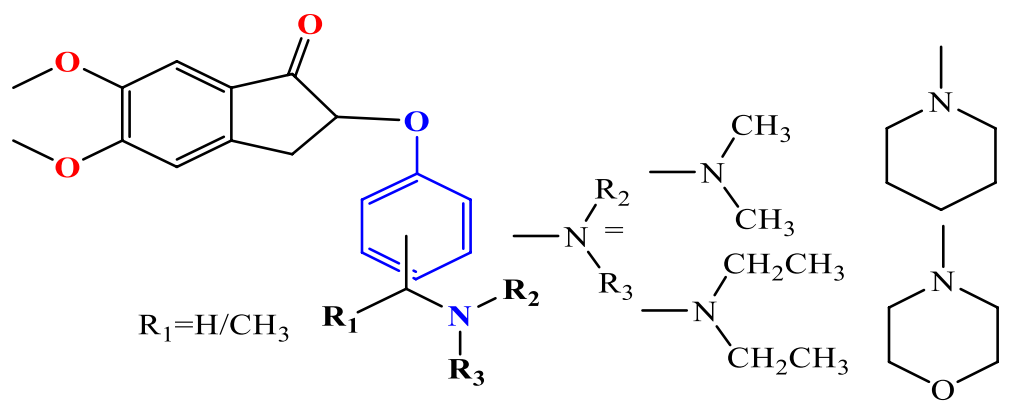

(17) 


\section{Phenoxy derivatives as anti-mycobacterial agents}

Twenty new classes of phenoxy acetic acid analogs were prepared by Mohammad Shahar yar et al. [57], and it was screened for anti-mycobacterial activity against $M$. tuberculosis H37Rv by using the technique BACTEC-460 radiometric system. The result of newly synthesized derivatives (18) showed promising activities against both drug-sensitive and drug-resistant strains of $M$. tuberculosis. These results indicated that the novel phenoxy acetic acids as an interesting lead molecule for further evaluation.

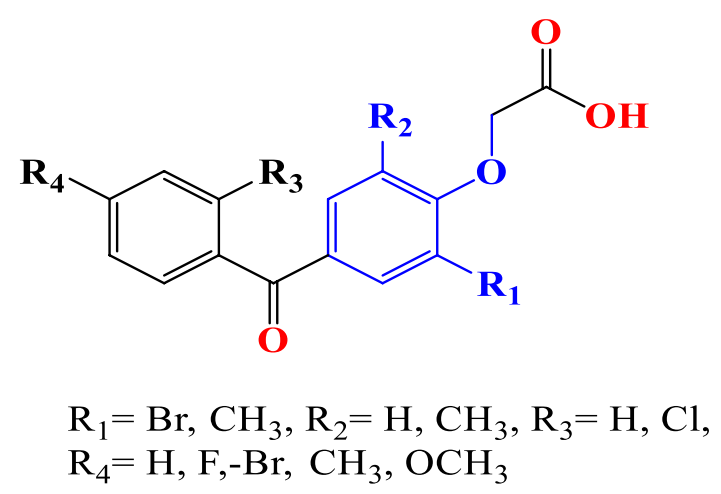

(19)

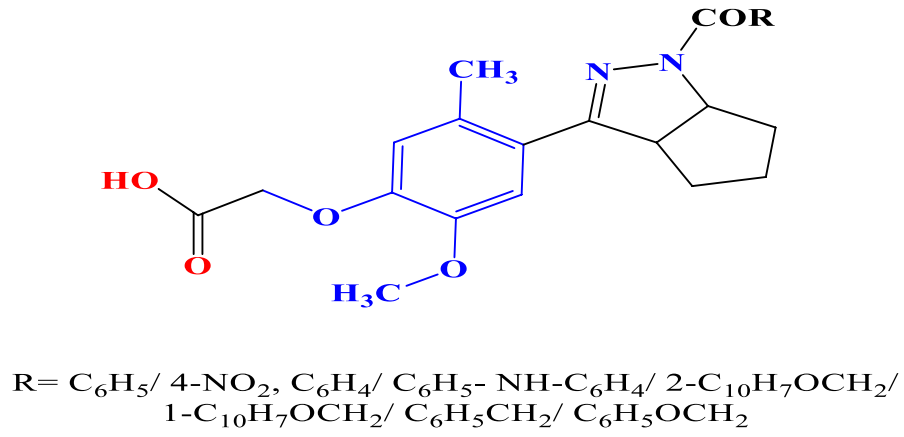

(18)

\section{Phenoxy derivatives as Anti-oxidant agents}

In 2013, our research group has been synthesized a series of (4-benzoyl-phenoxy)-acetic acid analogs (19) and then evaluated against in-vitro anti-oxidant effects by using 1 , 1-diphenyl-1-picrylhydrazyl (DPPH), hydrogen peroxide $\left(\mathrm{H}_{2} \mathrm{O}_{2}\right)$ and nitric oxide (NO) radical scavenging assays. Among the series, un-substituted and chloro derivatives exhibited good activities compared to the standard drug ascorbic acid [58].
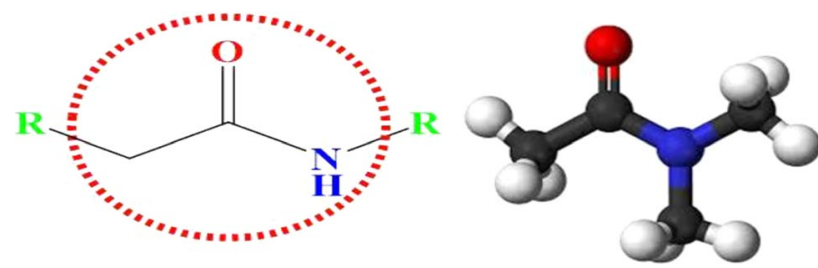

Fig. 2 Structure of acetamide showing a single peptide group

\section{An overview of acetamide derivatives as possible therapeutic candidates}

Acetamide (also known as ethanamide or acetic acid amide) belongs to the class of organic compounds known as carboxamides acids with the formula $\mathrm{CH}_{3} \mathrm{CONH}_{2}$ Fig. 2 [59]. It is associated with the class of acetamides that results from the condensation of acetic acid with ammonia as a monocarboxylic acid amide Scheme 4 [60]. Acetamide exists as a solid, soluble in water and an extremely weak acidic with a mousy tasting compound that can found in red beetroot.<smiles>CC(=O)OCC(N)=O</smiles>

Scheme 4 Synthesis of acetamide derivative 
The domain of drug research deals primarily with both the design and development of new drugs, based on an understanding as to how they function to target a particular gene at the molecular level [61]. Molecules with acetamide linkage and its derivatives as core structures are reported to exhibit a wide spectrum of biological activities [62]. Therefore, special attention has also been given to acetamide<smiles>CC(=O)Nc1ccc(O)cc1</smiles>

(23) sedative or analgesic properties, for example, paracetamol (23 and 24) is one of the world's most widely used as an analgesic and antipyretic agents bearing acetamide group [55]. Presumably, these are just some of the causes for increasing interest in the study of the synthesis, biological activity and structure-activity relationships of acetamide and its derivatives.<smiles>[R]c1c([R])c(NC(C)=O)c([R])c([R])c1O</smiles>

(24) medications because of their possible use as a therapeutic agent. Acetamide derivatives and their analogs representing a high potential of biological activities including anti-inflammatory [63], anti-oxidant [64], anti-cancer [65], anti-convulsant [66], anti-hypoxic and anti-microbial [67], antituberculosis agents [68] and anti-COVID-19 molecules [69]. In addition, several acetamide derivatives are used to improve some enzymes that inhibit HIV virus activity from replicating [70]. Acetamide derivatives found to possess

\section{Introduction to synthesis of acetamide and its derivatives}

Interestingly, our group have been designed and synthesized a novel $N$-(2-aminophenyl)-2-(2-isopropylphenoxy) acetamide (27) by the condensation of ethyl 2-(2 isopropylphenoxy) acetic acid (25) with 1,2-diaminobenzene (26), using dry DCM as solvent lutidine and TBTU as coupling agent at room temperature as shown in Scheme 5 [71].<smiles>CC(C)c1ccccc1OCC(=O)O</smiles>

(25)<smiles>Nc1ccccc1N</smiles>

(26)<smiles>CC(C)c1ccccc1OCC(=O)Nc1ccccc1N</smiles>

(27)

Scheme 5 Synthesis of isopropylphenoxy acetamide 
Moreover, our group also have been synthesized phenoxy acetamide pyridazine derivatives (30a-l) by coupling of phenoxy acetic acid derivatives (28a-l) with 3-chloro6-hydrazinylpyridazine (29) in the present of lutidine and TBTU as coupling agent [53] (Scheme 6).

The syntheses of the 2,2-diphenyl- $N$-(3-phenylpropyl) acetamide (32) as reported in Scheme 7 was accomplished by using 2,2-diphenylacetic acid (31) in dry DCM with $N, N 1$-carbonyldiimidazole (CDI) and 4-dimethyl aminopyridine (DMAP), and the reaction mixture was stirred for $20 \mathrm{~min}$ at room temperature. Then 3-phenylpropylamine was added and the mixture further stirred for $5 \mathrm{~h} \mathrm{[72].}$

\section{Pharmaceutical aspects of acetamide derivatives}

\section{Acetamide derivatives as analgesic agents}

A series of $N$-phenylacetamide sulphonamides were synthesized and interestingly in this series $N$-[4-[(4-methyl1-piperazinyl)sulfonyl]phenyl]acetamide (35) exhibited good analgesic activity as comparable or superior than paracetamol, while the compounds $N$-(4-(N,N-diethylsulfamoyl) phenyl)acetamide (36) and $N$-(4-(piperazin-1-ylsulfonyl) phenyl) acetamide (37) showed an important anti-hypernociceptive activity which is associated to inflammatory pain [74].<smiles>CC(=O)Nc1ccc(S(=O)(=O)N2CCN(C)CC2)cc1</smiles>

(35)<smiles>CC(=O)Nc1ccc(S(=O)(=O)N2CCNCC2)cc1</smiles>

(36)<smiles>CCN(CC)S(=O)(=O)c1ccc(NC(C)=O)cc1</smiles>

(37)
Besides, as shown in Scheme 8, 2-chloro- $N$-phenylacetamide (34) was synthesized by dissolving aniline (33) in benzene and triethylamine and then chloroacetyl chloride was added with constant stirring [73].

\section{Acetamide derivatives as anti-cancer agents}

A series of acetamide sulphonyl analogs have been designed and synthesized very recently through a multistep reaction and then screened for in-vitro cytotoxic 
<smiles>O=C(O)COc1ccc(Cl)cc1F</smiles>

(28a-l)<smiles>NNc1ccc(Cl)nn1</smiles>

(29)

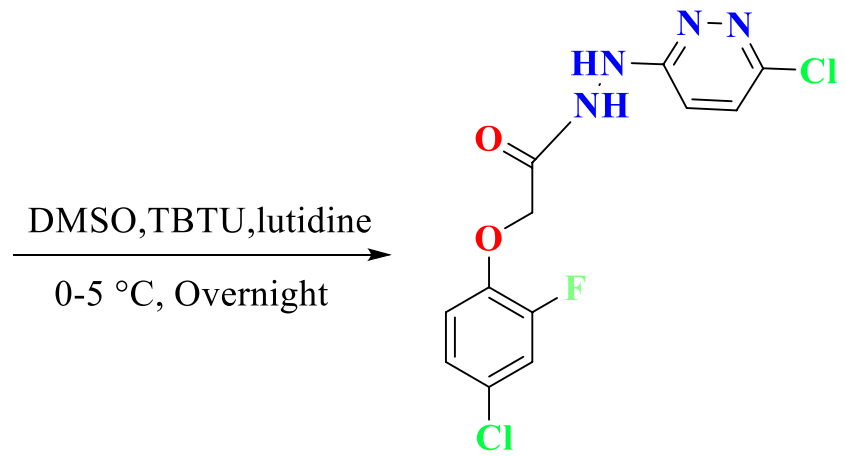

(30a-l)

Scheme 6 Synthesis of phenoxy acetamide pyridazine derivatives<smiles>O=C(O)C(c1ccccc1)c1ccccc1</smiles>

(31) 3-phenylpropylamine

CDI, DMAP, DCM

$25-30{ }^{\circ} \mathrm{C}, 20 \mathrm{~min}$<smiles>O=C(NCCCc1ccccc1)C(c1ccccc1)c1ccccc1</smiles>

(32)

Scheme 7 Synthesis of diphenylpropyl acetamide

Scheme 8 Synthesis of chlorophenyl acetamide

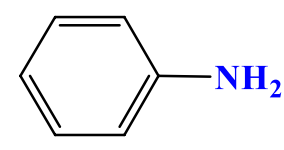

(33)
$\mathrm{ClCOCH}_{2} \mathrm{Cl}$,Triethyl amine Benzene, Overnight<smiles>O=C(CCl)Nc1ccccc1</smiles>

(34)

activity against a different human cancer cell lines such as HCT-1, SF268, HT-15, MCF-7 and PC-3, using the MTT assay. As per the results, most of the acetamides showed a good activity but compounds $N$-(4-methoxyphenyl)-2-(4-pyrrolidin-1-ylquinazoline-2-sulfonyl)acetamide (38), $N$-(2-methoxy-phenyl)-2-(4-piperidin-1-yl quinazoline-2-sulfonyl)-acetamide (39) and $N$-(4-methoxyphenyl)-2-(4-morpholin-4-ylquinazoline-2-sulfonyl)-acetamide (40) were showed remarkable anti-cancer activity on most tested cell lines [75]. 


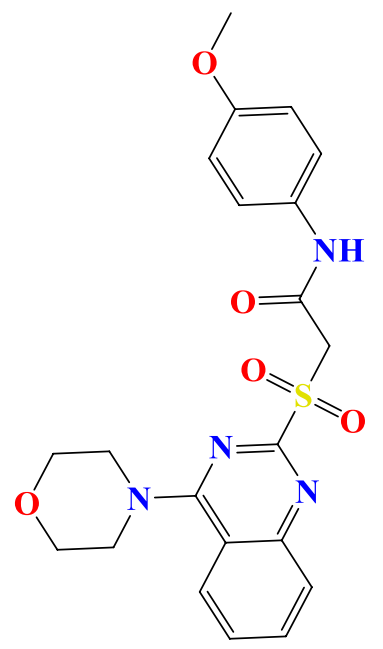

(38)

\section{Acetamide derivatives as anti-depressant, tranquilizer and anti-convulsant agents}

Researchers in search of novel anti-depressants prepared a series of triazino acetamides and evaluated against antidepressant activity by using tail suspension test in mice. The series exhibited a great anti-depressant activity, measured in terms of the percentage decrease in immobility duration. The synthesized derivatives (41-44) exhibited significant activity to reduced immobility compared to standard anti-depressant drugs like moclobemide, imipramine and fluoxetine [76].

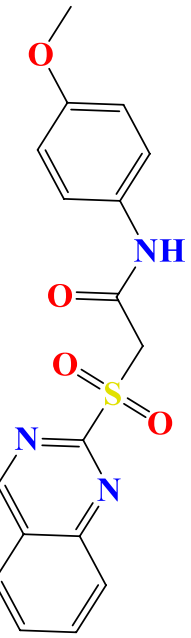

(39)<smiles>COc1ccccc1NC(=O)CS(=O)(=O)c1nc(N2CCCCC2)c2ccccc2n1</smiles>

(40)

Moreover, a simple and efficient method for the synthesis and evaluation of acetamides was developed by Ashok et al. [77] for anti-convulsant activity, along with the neurotoxicity effect on mice. Among all the synthesized compounds tested, (45) and (46) showed the highest activity with anti-convulsant potency relative to phenytoin of 0.74 and 0.72 , respectively. Whereas the other acetamide compounds shown moderate potencies in the range 0.21 to $0.64 \mathrm{com}-$ pared to phenytoin.<smiles>O=C(CSc1nnc2c(n1)[nH]c1ccccc12)Nc1ccccc1</smiles>

(41)<smiles>O=C(CSc1nnc2c(n1)[nH]c1ccccc12)Nc1ccc(Br)cc1</smiles><smiles>O=C(CSc1nnc2c(n1)[nH]c1ccccc12)Nc1ccc(Cl)cc1</smiles>

(42)<smiles>CCCCCCCCCCSc1nnc2c(n1)[nH]c1ccccc12</smiles>

(43) 


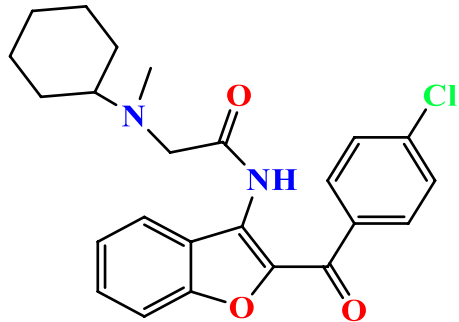

(45)

\section{Acetamide derivatives as anti-microbial and anti-fungal agents}

A new series of acetamides was prepared and characterized by different spectral data by Ravindra et al. [78] All acetamide derivatives were screened to evaluate anti-microbial and anti-fungal activity. The experiments were performed and disclosed that the acetamide compounds 2-(4-(benzo[d] thiazol-5-ylsulfonyl)piperazin-1-yl)- $N$-(3,5-difluorophenyl) acetamide (47) and 2-(4-(benzo[d]thiazol-5-ylsulfonyl) piperazin-1-yl)- $N$-(3-isopropylphenyl) acetamide (48) were displayed good activity against gram-positive bacteria. As well as the other two acetamide compounds 2-(4-(benzo[d] thiazol-5-ylsulfonyl)piperazin-1-yl)- $N$-(thiazol-2-yl)acetamide (49) and 2-(4-(benzo[d]thiazol-5-ylsulfonyl)piperazin1 -yl)- $N$-(6-chloropyridin -2-yl) acetamide (50) were showed good activity against fungi.

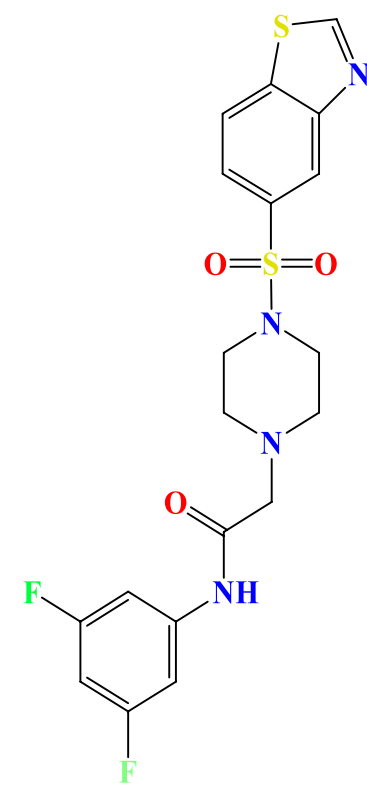

(47)

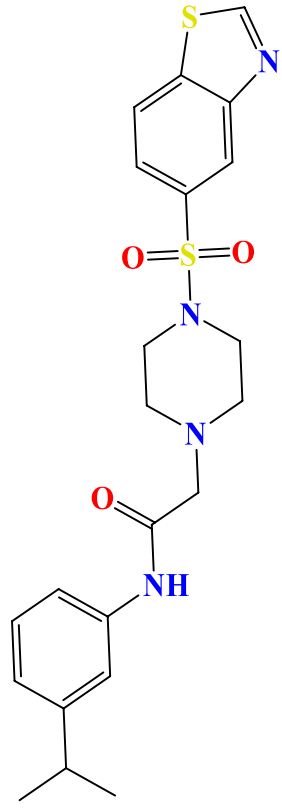

(48)<smiles>CC1CCN(CC(=O)Nc2c(C(=O)c3ccc(Cl)cc3)oc3ccccc23)CC1</smiles>

(46)
Chalcone are compounds that consists of two aromatic rings linked by $\alpha, \beta$-unsaturated ketone, with various substituents on the two aromatic rings (51 and $\mathbf{5 2}$ ), and they forms the central core for a variety of important biological compounds [79]. Various methods are presented to synthesized chalcones and its derivatives; one of them is Claisen-Schmidt condensation of aryl aldehyde derivatives and acetophenone analogs [80]. Due to their various biological and pharmacological properties, chalcones and its derivatives are intensely involved in the medicinal and industrial aspects [81]. Natural and synthetic chalcones exhibit a wide variety of biological properties including anti-proliferative [82], anti-inflammatory [83], anti-cancer [84], anti-tubercular and anti-bacterial<smiles>O=C(CN1CCN(S(=O)(=O)c2ccc3scnc3c2)CC1)Nc1cccc(Cl)n1</smiles>

(49)<smiles>O=C(CN1CCN(S(=O)(=O)c2ccc3scnc3c2)CC1)Nc1nccs1</smiles>

(50) 
[85], anti-fungal [86], anti-oxidant [87] and anti-leishmanial activities [88]. In addition, naturally occurring chalcones are precursors in the biosynthesis of chromanones and flavanones and play a significant role in the plant protection against ultraviolet radiation, diseases and insects [89].

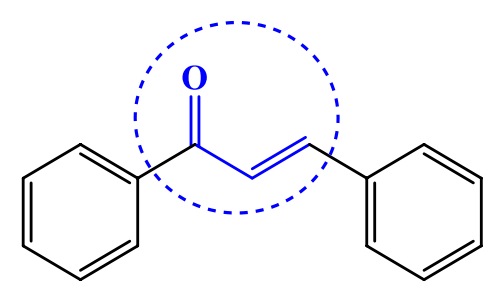

(51)
1,1',1'"-(2,4,6-Trimethoxybenzene-1,3,5-triyl)triethanone (60) by the reaction of compound (59) with dimethyl sulphate. To the solution of compound (60) and benzaldehyde derivatives (61a-i) in methanol, potassium hydroxide solution was added and stirred for $14 \mathrm{~h}$ at $25{ }^{\circ} \mathrm{C}$. After the

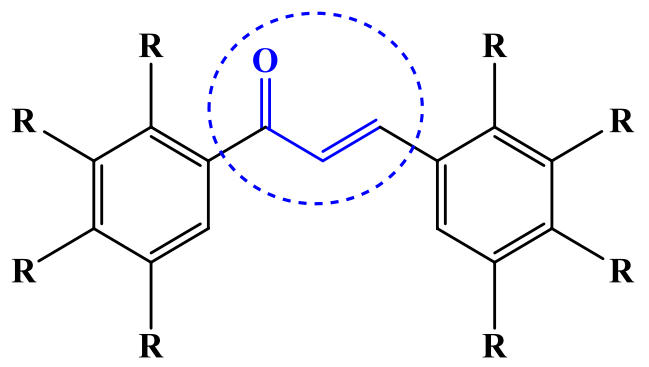

\section{Introduction to synthesis of chalcone and its derivatives}

Chemically, chalcone (51) is obtained by an Aldol condensation between aromatic aldehydes (benzaldehyde) (53) and aromatic ketones (acetophenone) (54) using sodium hydroxide as a catalyst which leads to $\alpha, \beta$-unsaturated carbonyl system as shown in Scheme 9 [90].

Interestingly, our group introduced an efficient and facile base-catalyzed Claisen-Schmidt condensation method to synthesize 1-(3,4-dimethoxyphenyl)-3-(4- bromophenyl)prop-2-en-1-one (57) by stirring a ethanolic solution of p-bromo benzaldehyde (55) and 3, 4-dimethoxy acetophenone (56) for $4-5 \mathrm{~h}$ in the presence of $10 \%$ potassium hydroxide solution as shown in Scheme 10 [91].

Further, a novel series of fluoro-substituted chalcone derivatives $(\mathbf{6 2} \mathbf{a}-\mathbf{i})$ were prepared by three steps reaction. First phloroglucinol (58) was treated with acetic anhydride in the presence of methane sulfonic acid at $80{ }^{\circ} \mathrm{C}$ to achieve compound 1,1',1"'-(2,4,6-trihydroxybenzene-1,3,5-triyl) triethanone (59). The next step was to obtain compound completion of reaction, solvent was removed and crude sample was treated with $2 \mathrm{M}$ hydrochloric acid solution, extracted with DCM and purified via column chromatography to yield chalcone compounds (62a-i) as depicted in Scheme 11 [92].

Many chalcones also can be obtained via coupling reactions by using different reactants (63-69). Several reactions involved $\mathrm{C}-\mathrm{C}$ and $\mathrm{C}$-heteroatom covalent bond via oxidative addition transmetalation-reductive elimination, as illustrated in Scheme 12 [93].

In general, chalcones synthesis was carried out through the condensation method in the presence of acid or base catalysis. At present due to their wonderful biological activities, various synthetic methodologies and procedures were reported which include various methods such as:

\section{Microwave irradiation condition}

Recently microwave solvent-free method was employed to prepare different chalcones (72). This method has more features over other conventional methods because it minimizes<smiles>O=Cc1ccccc1</smiles>

(53)<smiles>CC(=O)c1ccccc1</smiles>

(54)

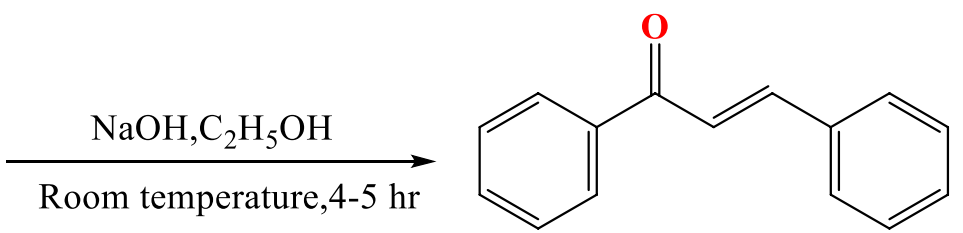

(51)

Scheme 9 Synthesis of chalcone derivatives 
<smiles>[R20]C(O)[C@H](O)[C@@H](C)OC</smiles>

(55)

(56)

(57)

Scheme 10 Synthesis of dimethoxy chalcone<smiles>Oc1cc(O)cc(O)c1</smiles>

(58)<smiles>CC(=O)c1c(O)c(C(C)=O)c(O)c(C(C)=O)c1O</smiles>

(59)<smiles>C#CCOc1c(C(C)=O)c(OC)c(C(C)=O)c(OC)c1C(C)=O</smiles>

(60)<smiles>[R]c1ccc(C=O)cc1</smiles>

(61a-i)

Reagents: (i) $\left(\mathrm{CH}_{3} \mathrm{CO}\right)_{2} \mathrm{O}, \mathrm{CH}_{3} \mathrm{COOH}, \mathrm{CH}_{3} \mathrm{SO}_{2} \mathrm{OH}$, $80{ }^{\circ} \mathrm{C}$; (ii) $\left(\mathrm{CH}_{3} \mathrm{O}\right)_{2} \mathrm{SO}_{2}, \mathrm{~K}_{2} \mathrm{CO}_{3}$, Acetone, reflux; (iii) $50 \% \mathrm{KOH}, \mathrm{MeOH}, \mathrm{RT}$

62a: $\mathrm{R}=2-\mathrm{F}, 62 \mathrm{~b}: \mathrm{R}=3-\mathrm{F}$

62c: $R=4-F, 62 d: R=2,4-d i F$

62e: $\mathrm{R}=2,3-\mathrm{diF}, 62 \mathrm{f}: \mathrm{R}=2,5-\mathrm{diF}$

62g: $\mathrm{R}=3,4-\mathrm{diF}, 62 \mathrm{~h}: \mathrm{R}=3,5-\mathrm{diF}$

62i: $\mathrm{R}=2,4,5-\operatorname{triF}$<smiles>[R][X]1cccc(/C=C/C(=O)c2c(OC)c(C(=O)C=C)c(OC)c(C(=O)/C=C/c3ccccc3)c2OC)c1</smiles>

$(62 \mathrm{a}-\mathrm{i})$

Scheme 11 Synthesis of different chalcone derivatives

the reaction time, solvent evaporation and most importantly with best yield of the product Scheme 13 [94].

\section{Ultrasound irradiation technique}

Ultrasound irradiation is one of the beneficial techniques, because it saves the reaction time by an increase in the vibrational state of the lattice that makes chemical reactions in a short time. In view of this, Chtourou et al. [95] reported a solvent-free synthesis of chalcones (73) with high yield using acidic KSF clay under the ultrasonic irradiation technique Scheme 14.

\section{Witting reactions}

Witting olefination is a method for the synthesis of chalcones by taking into account the basic function of chalcones as $\alpha$, $\beta$-unsaturated carbonyl derivatives. In light of this, Ramirez 
<smiles>C#Cc1ccccc1</smiles>

(63)<smiles>CCSCC=Cc1ccccc1</smiles>

(64)<smiles>COc1ccccc1</smiles>

(66)
(53)<smiles>O=C(Cl)c1ccccc1</smiles>

(65)<smiles>O=C(Cl)c1ccccc1</smiles>

(65)<smiles>O=C(O)/C=C\c1ccccc1</smiles><smiles>CC(O)c1ccccc1</smiles><smiles>C#Cc1ccccc1</smiles>

(63)
(53)<smiles>O=Cc1ccccc1</smiles>

(69)

Scheme 12 Many chalcones obtained via coupling reactions

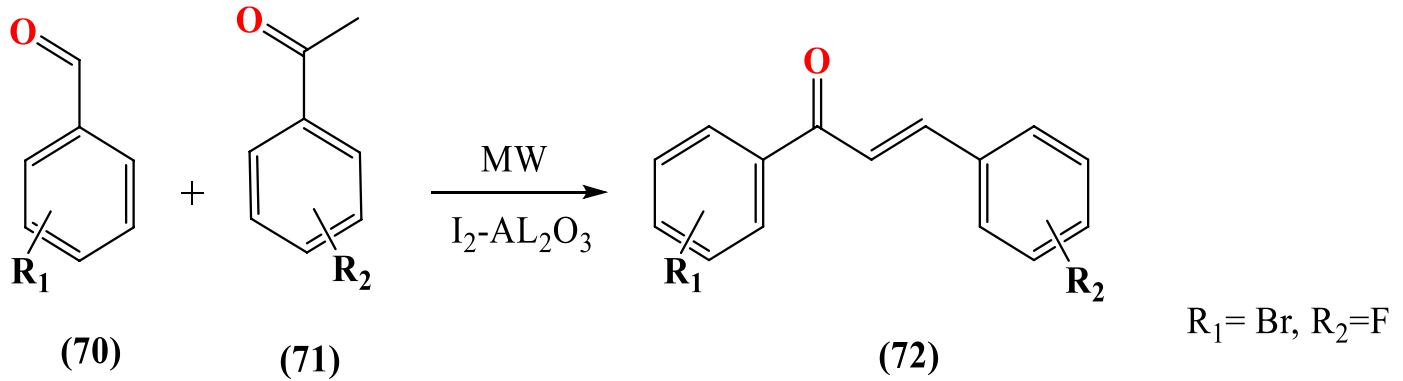

Scheme 13 Different chalcones synthesis via microwave solvent-free method

Scheme 14 Synthesis of chalcones derivatives using ultrasonic irradiation technique<smiles>[R][X]c1ccc(C(=O)/C=C/c2ccccc2)cc1</smiles>

(54)
(73)
$\mathbf{R}=\mathbf{B r}$ 
Scheme 15 Synthesis of chalcones using Witting reaction method<smiles>O=Cc1ccccc1</smiles>

(70)<smiles>O=C(C=[PH2])c1ccccc1</smiles>

(74)<smiles>O=C(/C=C/c1ccccc1)c1ccccc1</smiles>

(51) et al. [96] were achieved the new chalcones (51) by refluxing triphenyl benzoyl methylene phosphorane (74) and benzaldehyde (70) using tetra hydro furan as solvent Scheme 15.

\section{Pharmaceutical aspects of chalcone derivatives}

\section{Chalcone derivatives as anti-cancer agents}

In the year of 2019, Lina et al. [97] have been synthesized two new series of chalcone derivatives through ClaisenSchmidt condensation. In the two series, compounds (E)-5-(3-(4-chlorophenyl) acryloyl)-2-methoxybenzenesulfonamide (75) and (E)-N-(4-amino-2-(methylthio)-6oxo-1,6-dihydropyrimidin-5-yl)-5-(3-(4-chlorophenyl) acryloyl)-2 methoxy benzenesulfonamide (76) exhibited potent anti-cancer activity against the majority of cell lines, especially HCT-116 for compound (75) and SF539 for (76) compound.
Likewise, in 2020 a series of coumarin-chalcone were synthesized and evaluated for anti-cancer potency by $\mathrm{Yu}$ Wang et al. [98] Among all compounds, (E)-7(diethylamino)-3-(3-(3-hydroxy-4-methoxyphenyl)-3-oxoprop-1-en-1-yl)-2H-chromen-2-one (77) with red fluorescence has been developed as cancer treatment agent. Further, this studies displayed that compound (77) induces cancercell apoptosis.<smiles>CCN(CC)c1ccc2cc(/C=C/C(=O)c3ccc(OC)c(O)c3)c(=O)oc2c1</smiles>

(77)<smiles>COc1ccc(C(=O)/C=C/c2ccc(Cl)cc2)cc1S(N)(=O)=O</smiles>

(75)<smiles>COc1ccc(C(=O)/C=C/c2ccc(Cl)cc2)cc1S(=O)(=O)Nc1c(N)nc(SC)[nH]c1=O</smiles>

(76) 


\section{Chalcone derivatives as anti-inflammatory and anti-depressant agents}

Zhe-Hao et al. [99] were designed, synthesized and evaluated twenty four quinoline-chalcone analogs against antidepressants and anti-inflammatory effects. The results illustrated that compounds (78-80) displayed the more antidepressant activity by shortened immobility times. Likewise, the same compounds exhibited moderate COX-2 inhibitory effects similar to standard drug celecoxib.

\section{Chalcone derivatives as anti-bacterial agents}

Due to the increase in anti-biotic resistance and other factors the researchers has been encouraged to look for new active compounds against multidrug-resistant pathogens. In this connection, compounds (81-88) were developed by Man Xu et al. [100] and screened for anti-bacterial activity which displayed good result.

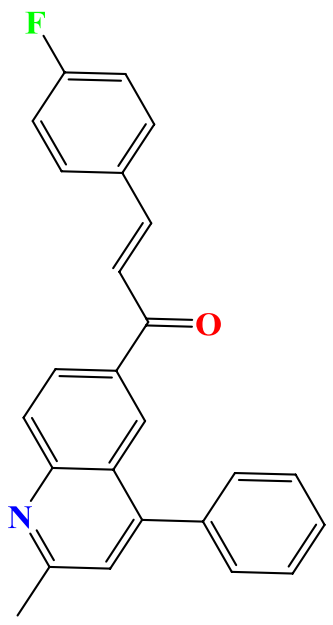

(78)

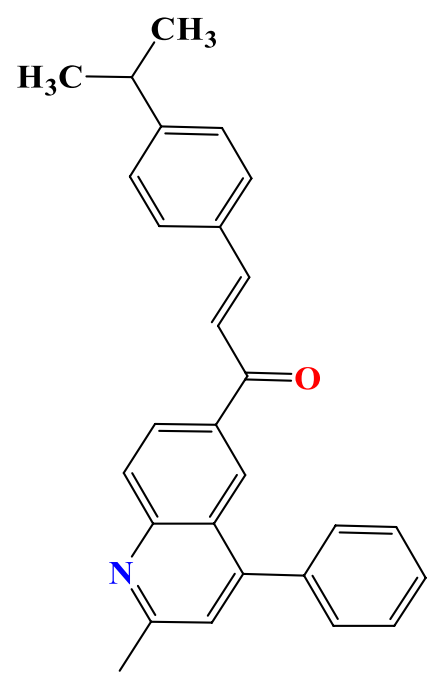

(79)

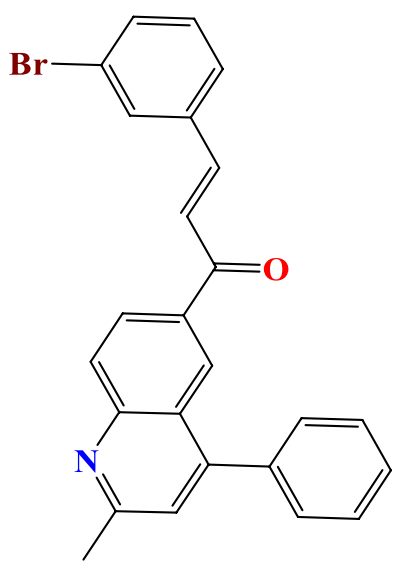

(80) 
<smiles>[R]Oc1c(/C=C/C(=O)c2ccc(O)cc2)ccc(O)c1/C=C/C(C)C</smiles>

(81)
(82)<smiles>Cc1cc(C)cc(-c2ccc(N3CCNCC3)c(/C=C/C(=O)c3cccc(NCCN)c3)c2)c1</smiles>

(83)<smiles>COc1ccc(/C=C/C(=O)c2c(O)cc(OC)cc2OC)cc1</smiles>

(84)<smiles>O=C(/C=C/c1ccccn1)c1ccc(N2C[C@H](CNC(O)=S)OC2=O)cc1</smiles>

(85)<smiles>O=C(/C=C/c1c2ccccc2cc2ccccc12)c1ccc2ccccc2c1</smiles>

(86)<smiles>O=C(/C=C/c1c2ccccc2cc2ccccc12)c1ccc2c(c1)-c1ccccc1C2</smiles>

(87)<smiles>O=C(/C=C/c1c2ccccc2cc2ccccc12)c1ccc2c(c1)Sc1ccccc1N2</smiles>

(88)

\section{Chalcone derivatives as anti-oxidant agents}

Very recently Afzal et al. [101] have been synthesized a new series of chalcones conjugated with isoxazole ring and evaluated for their anti-oxidant activity which displayed superior anti-oxidant potency. Among the synthesized chalcone derivatives, compounds (89) with three methoxy groups at 2, 4 and 6-positions and (90) with one methoxy group at 2-position exhibited potent anti-oxidant activities and its potency were near equal to the standard compound. 
Fig. 3 Heterocycles comprising nitrogen atoms

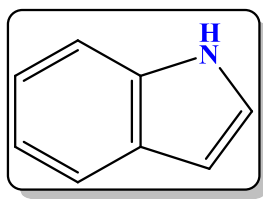

Indole

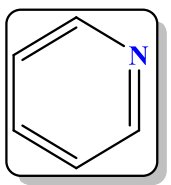

Pyridine

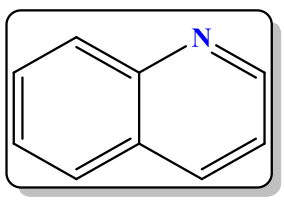

Quinoline

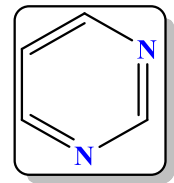

Pyrimidine

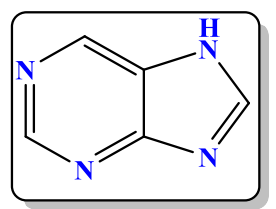

Purine

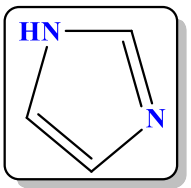

Imidazole

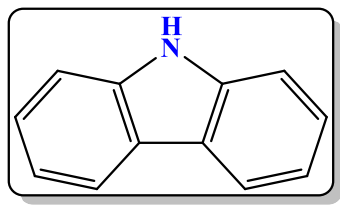

Carbazole

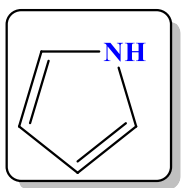

Pyrrole<smiles>COc1cc(OC)c(/C=C/C(=O)c2ccno2)c(OC)c1</smiles>

(89)<smiles>COc1ccccc1/C=C/C(=O)c1ccno1</smiles>

(90)

\section{An overview of heterocycles containing nitrogen as possible therapeutic candidates}

A cyclic organic compound that contains all carbon atoms in the formation of a ring is called a carbocyclic compound. When a component of the carbocyclic ring system replaced by at least one hetero atom such as oxygen, nitrogen, sulphur etc., then it is referred as a heterocyclic compound. Owing to its abundance in natural resources and various biological activities, heterocyclic chemistry is amongst the most important sources of new drugs within the medical society [102]. It is in this sense that scientists are pouring most of their effort currently is focusing on studying the chemistry of heterocyclic compounds because of their great importance, whether in the pharmaceutical side or in other industrial applications [103, 104]. Therefore, it still draws the attention of researchers working not just in the field of natural products but also from the field of synthetic organic chemistry. The chemistry of the heterocyclic compounds that contain nitrogen within their composition shows a dynamic role in medicinal chemistry and has paying healthy interest due to their unique pharmacological properties [105].
Heterocycles comprising nitrogen atoms such as quinolines, indoles, purine, carbazole, pyridine, pyrimidine, imidazole and pyrrole Fig. 3 demonstrate a variety of biological activities, and their synthetic methods have become an interesting field in medicinal chemistry [106].

In nature, many of the nitrogen-heterocyclic compounds are widely spread to possess complex pharmacological and physiological activities and are components of several molecules of biological importance, including nucleic acids, vitamins, pharmaceuticals, antibiotics, pigments and agrochemicals [107-111]. Moreover, the electron-rich nitrogen containing heterocycle is not only able to easily accept or donate a proton, but it could also easily establish numerous weak interactions that can help them to bind with various enzymes and receptors in biological targets with extremely affiliated therapeutic properties [112-115].

The aza heterocycles are important structural units in the marketed drugs [116]. Nearly two-thirds of the main small molecule drugs have a minimum one aza heterocyclic fragment in their design structures [117]. Whereas nitrogen-based synthetic heterocyclic compounds provide broad therapeutic applications in several medical categories, 
such as VEGFr-2 inhibitors (91) [118], anti-cancer [119], anti-tubulin (92) [120], anti-inflammatory [121], antiaging [122], anti-tumor (93) [123], anti-influenza [124], anti-tubercular [125], anti-bacterial [126], anti-diabetic [127], anti-dengue virus [128], anti-convulsant and antidepressant [129], promising antioxidant, antifungal and anti-acetylcholinesterase agents (94) [130]. Moreover, they have been widely found as a key structural material and dominate the field of dyestuff synthesis [131], agro-based chemicals [132] and supramolecular chemistry [133]. They have attracted attention because of their synthetic utility in catalysis [134], photosensitizers [135], polymer chemistry [136] and nanotechnology applications [137]. Therefore, considerable attention needs to be given in order to develop effective new techniques to synthesize various novel aza heterocyclic candidates.

\section{An overview of indole as possible therapeutic candidates}<smiles>c1ccc2[nH]ccc2c1</smiles>

(95)

In drug discovery, the core value of heterocyclic systems for therapeutic chemists is the ability to synthesize one library focusing on a single central scaffold and test it

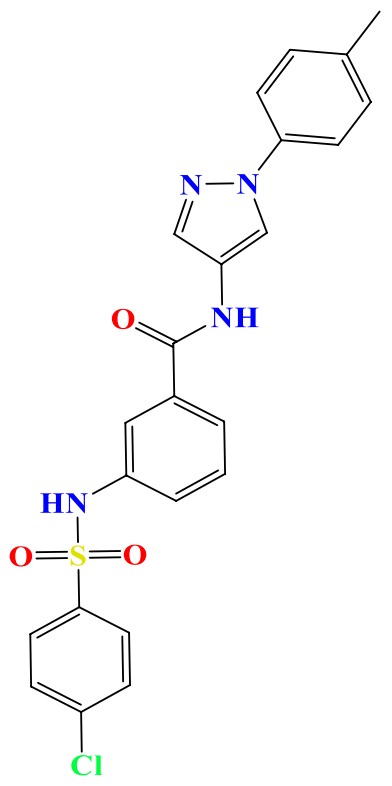

(91)<smiles>C=C(c1ccc2c(ccn2C)c1)c1cc(CO)nc2ccccc12</smiles><smiles>CCc1nc2ccccc2n1C</smiles><smiles>[14CH2]N=[Al]</smiles><smiles>c1cnc2[nH]cc(-c3ccnc(NCC4CCNCC4)n3)c2c1</smiles>

(93)
(94)
By incentivized the information provided from the above literature, this work involves the synthesis, characterization and pharmacological application of heterocyclic indole and quinoline derivatives. against a variety of different receptors which involved in different pathways, producing multiple active compounds [138]. Indole is a heterocyclic compound with a molecular formula of $\mathrm{C}_{8} \mathrm{H}_{7} \mathrm{~N}$ and characterized as a six-membered 
Fig. 4 The different types of indole synthesis

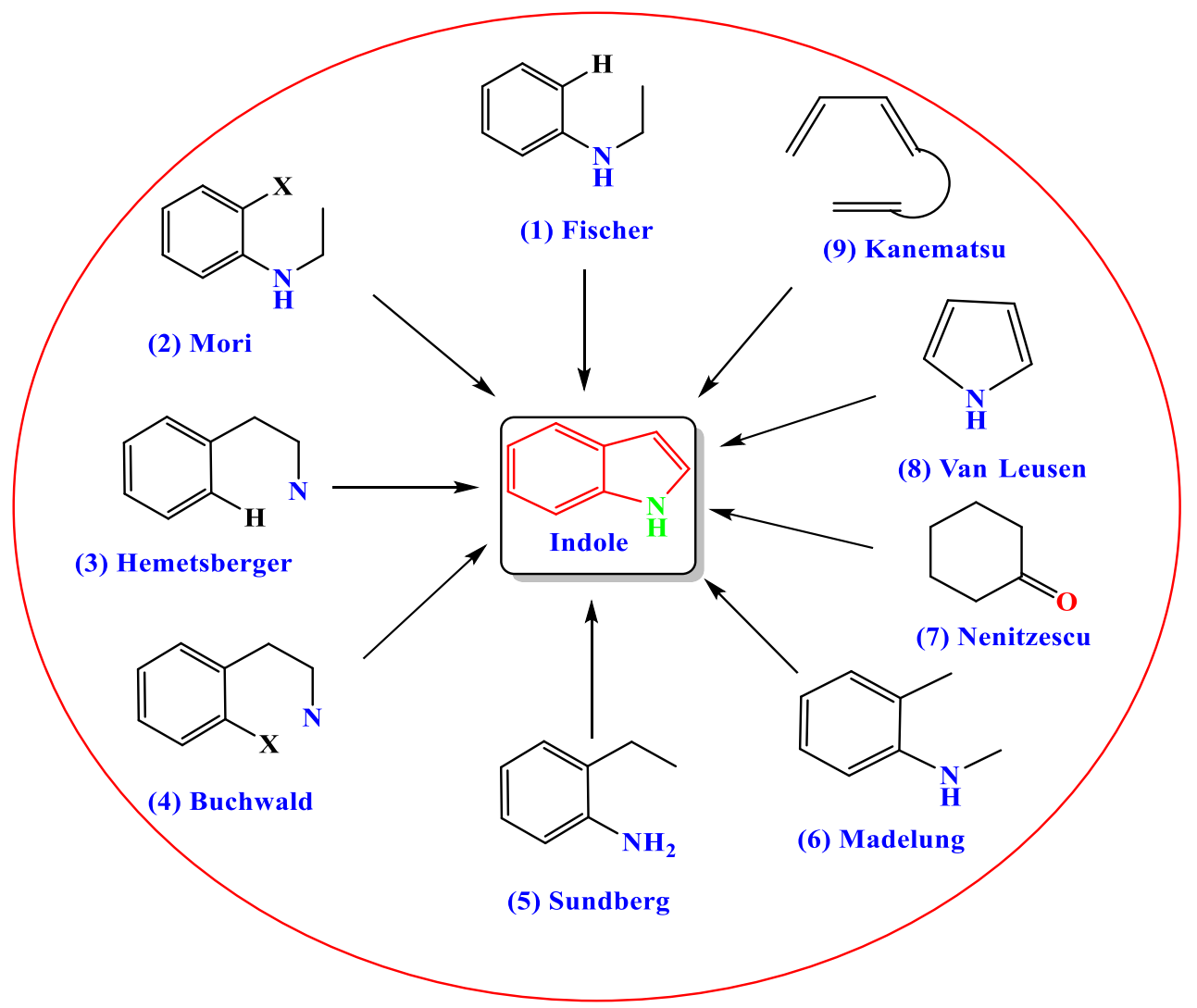

Scheme 16 Synthesis of indole derivatives<smiles>NNc1ccccc1</smiles>

(96)<smiles>[R]CC([R2])=O</smiles>

(97)

(98)<smiles>O=Cc1c[nH]c2ccccc12</smiles>

(99)<smiles>[R]OC(=O)NN</smiles>

(100)<smiles>NC(N/N=C/c1c[nH]c2ccccc12)=[Ni]Cl</smiles>

(101)

Scheme 17 Synthesis of new indole derivative 


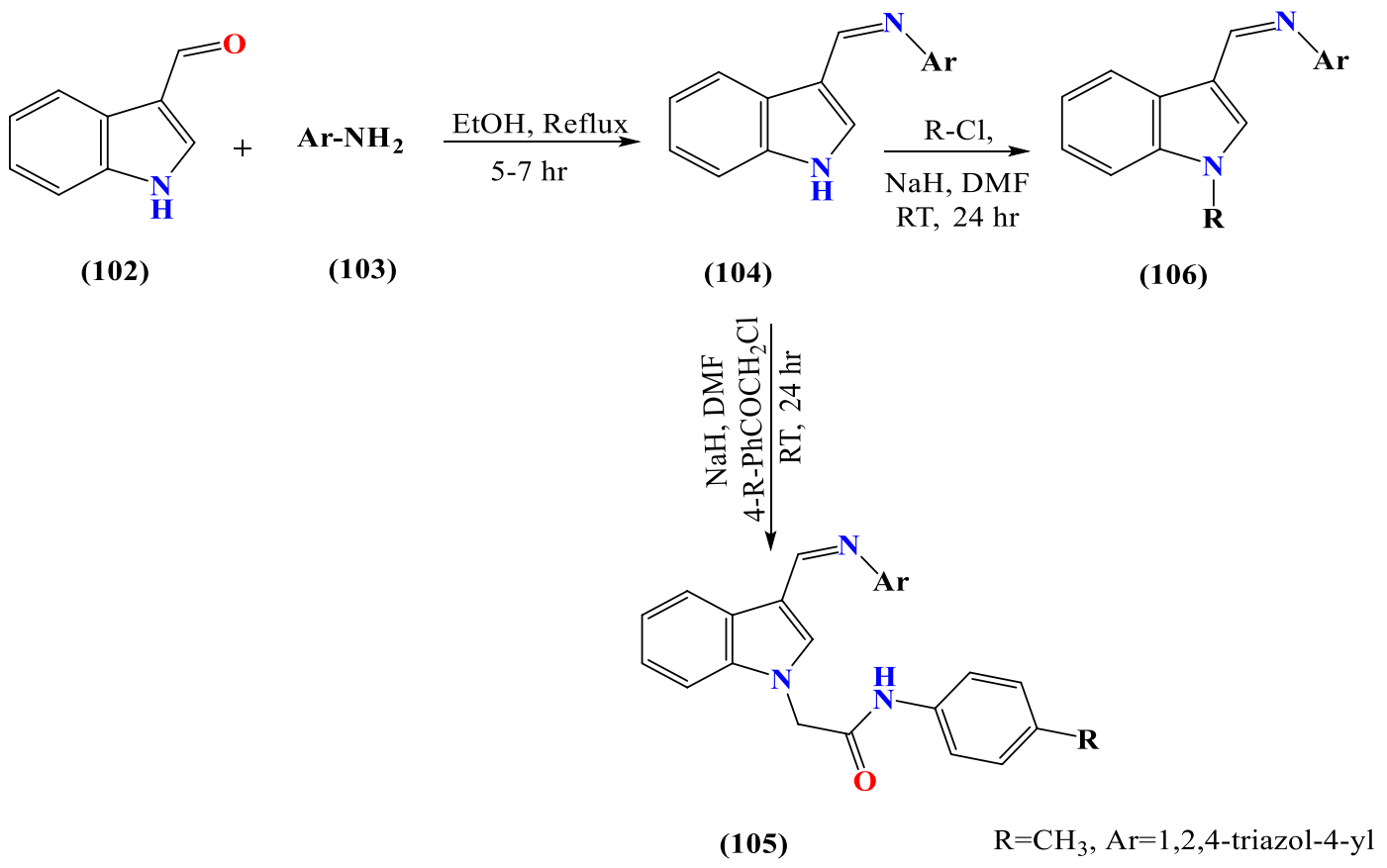

Scheme 18 Synthesis of two new series of indole derivatives<smiles>O=C(O)c1cc2ccccc2[nH]1</smiles>

(107)<smiles>[R20]CC(=O)OC(C)N</smiles>

(108)<smiles>NNC(=O)c1cc2ccccc2[nH]1</smiles>

(109)<smiles>O=C(N/N=C/[Al])c1cc2ccccc2[nH]1</smiles>

(110)

Scheme 19 Synthesis of indole hydrazone derivative

benzene ring fused to a five-membered pyrrole ring. It has a bicyclic structure and the most basic indole is shown above (95), which found in many natural and synthetic molecules that are associated with several biological activities [139]. The indole nucleus as a versatile and unique scaffold is frequently found in the medicinal chemistry and experimental drug design field with marvellous characteristics
[140]. Due to the presence of an electron-rich pyrrole moiety $[141,142]$, that can use non-covalent interactions with various other molecules through hydrogen bonding formation between NH moiety and $\pi-\pi$ system [143]. Because of this ideal property, indole and its diverse derivatives are widely used for the design and development of novel drugs [144]. A broad range of pharmacological applications has 
<smiles>O=Cc1cc2ccccc2[nH]1</smiles>

(111)<smiles>NNC(=O)c1ccc(O)cc1</smiles>

(112)

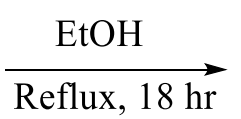<smiles>O=C([Al])N/N=C/c1cc2ccccc2[nH]1</smiles>

(113)

Scheme 20 Synthesis of indole benzo-hydrazone derivative

been linked to natural and artificial molecules that hold an indole nucleus, providing it an appropriate building block for several therapeutic agents [145]. Indole derivatives are commonly present in many natural products that occur in various types of plants, fungi, animals and marine species [146]. For instance, it is present in tryptophan (essential amino-acid), serotonin (neurotransmitter found in all bilateral animals), indole-3-acetic acid (plant hormone from auxin class) and melatonin (hormone found in animals, plants and microorganisms), etc. [147]. Therefore, it got high attention to the development of new synthetic methods and the confirmation of their pharmacological activities involving anticancer [148, 149], anti-inflammatory, anti-oxidative [150], anti-histamines [151], anti-HIV [152], anti-microbial [153] and cardiovascular [154].

Indole and its analogs are crucial and play a vital role in drugs targeting the immune system [155]. Furthermore, many of indole derivatives are considered as potent scavengers of free radicals [156]. The various studies including in-vitro and in-vivo investigations have shown that indole moiety substances can effectively inhibit type 2 diabetic activity [157, 158]. Thus, over the years the development and selective designing of indole and its derivatives have always been at the heart of the current investigation of new and highly effective drugs [159].

\section{Introduction to synthesis of indole and its derivatives}

There are many methods and reactions associated with indole synthesis involving Fischer, Hemetsberger, Madelung, Nenitzescu, Sundberg, Mori, Buchwald, Van Leusen and Kanematsu synthesis as represent in Fig. 4 [160]. For example, one of the oldest and most widely used and versatile methods for indole synthesis $(\mathbf{9 8})$ is the Fischer indole synthesis that started in the year 1883 with substituted phenylhydrazine (96) and an aldehyde or ketone (97) under acidic conditions. Today the anti-migraine drugs of the triptan group are still synthesized by this old method Scheme 16 [161].

Sandes et al. [162] reported the synthesis of new indole derivative (101) by refluxing a mixture of $1 H$-indole-3-carbaldehyde (99) and hydrochloride of aminoguanidine (100), for $20 \mathrm{~min}$ as depicted in Scheme 17.

Interestingly, Lamie et al. [163] has been prepared two new series of indole derivatives by refluxing ethanolic mixture of indole-3-carboxaldehyde (102) and primary amine (103) to get intermediate (104), which on reacting with substituted chloroacetophenone and aromatic halide separately afforded compounds (105) and (106), respectively, as shown in Scheme 18.

In addition, in 2019 two novel series of indole analogs has been synthesized by Monica Demurtas et al. [164] starting with $1 H$-indole-2-carboxylic acid (107) which initially converted into the corresponding ester (108). In next step, ester (108) was refluxed with hydrazine hydrate to get $1 \mathrm{H}$-indole2-carbohydrazide (109). Finally, indole hydrazone derivative (110) was achieved by coupling the intermediate (109) with the suitable aryl-aldehyde Scheme 19. Besides, indole benzo-hydrazone derivative (113) was achieved by coupling indole-2-carboxaldehyde (111) with the suitable hydroxybenzo-hydrazide (112) as shown in Scheme 20.

\section{Pharmaceutical aspects of indole derivatives}

Indole derivatives as anti-cancer agents In an effort to recognize the potential anti-cancer agents, some new indole derivatives have been prepared and tested against three cancer cell lines (HCT-116, HepG-2, and MCF7) based on sulforhodamine $B$ assay. Further, among the series, compounds $\mathrm{N}$-(3-(2-(5-(morpholinosulfonyl)-2oxoindolin-3-ylidene)acetyl) phenyl)acetamide (114), 4-(2-(5-(morpholinosulfonyl)-2-oxoindolin-3-ylidene) acetyl) phenyl acetate (115), 2-(5-(morpholinosulfonyl)- 
2-oxoindolin-3-ylidene) malononitrile (116) and (E)-ethyl 2-cyano-2-(5 (morpholinosulfonyl)-2-oxoindolin-3-ylidene) acetate (117) showed broad-spectrum of anti-cancer potency on the tested cancer cell lines and also showed good $\mathrm{IC}_{50}$ values [165].<smiles>CC(=O)Nc1cccc(C(=O)/C=C2\C(=O)Nc3ccc(S(=O)(=O)N4CCOCC4)cc32)c1</smiles>

(114)<smiles>N#CC(C#N)=C1C(=O)Nc2ccc(S(=O)(=O)N3CCOCC3)cc21</smiles>

(116)
Indole derivatives as anti-oxidant, anti-bacterial and cytotoxicity agents Recently in a search for novel drugs as anti-oxidant and anti-bacterial, and cytotoxicity activities, a series of new indole derivatives were prepared via the Knoevenagel reaction in. Besides, they were subjected to in-vitro<smiles>CC(=O)Oc1ccc(C(=O)/C=C2\C(=O)Nc3ccc(S(=O)(=O)N4CCOCC4)cc32)cc1</smiles>

(115)<smiles>CCOC(=O)/C(C#N)=C1/C(=O)Nc2ccc(S(=O)(=O)N3CCOCC3)cc21</smiles>

(117) anti-bacterial investigation and showed that the compounds with halogen substituent such as 8-chloro-2-methyl-3oxo- $2,3,9,10$ tetrahydropyrido $\left[4^{\prime}, 3^{\prime}: 3,4\right]$ cyclopenta $\quad[1,2-b]$ indole-4-carbonitrile (118) had strong inhibitory action. Regarding anti-oxidant screening, compounds $(E)$-2-cyano2-(5-methyl-3,4-dihydrocyclopenta[b]indol-1(2H)-ylidene) acetamide (120), (E)-2-(5-chloro-3,4-dihydrocyclopenta[b] indol-1(2H)-ylidene)-2-cyanoacetamide (121) and (118) showed a great activity compared with the reference drug. Finally, cytotoxic activity was also evaluated and compounds (118) and (119) exhibited interesting cytotoxicity activity [166]. 
<smiles>Cn1cc2c(c(C#N)c1=O)-c1c([nH]c3c(Cl)cccc13)C2</smiles>

(118)<smiles>Cc1cccc2c3c([nH]c12)CCC3=C(C#N)C(N)=O</smiles>

(120)<smiles>Cn1cc2c(c(C#N)c1=O)-c1c([nH]c3c(Br)cccc13)C2</smiles>

(119)<smiles>N#C/C(C(N)=O)=C1\CCc2[nH]c3c(Cl)cccc3c21</smiles>

(121)
Indole derivatives as anti-inflammatory agents Recently Yuanzheng Huang et al. [167] have been designed and synthesized a series of novel indole amide analogs. Besides, they were evaluated for in-vivo anti-inflammatory activity. The result displayed that, compounds (5-chloro-1-(4-chlorobenzyl)-1H-indol-2-yl)(4-((3,5,6-trimethylpyrazin-2-yl)methyl)piperazin-1-yl)methanone (122), 5-chloro-1-(4-fluorobenzyl)- $N$-(2-(5-methoxy$1 H$-indol-3-yl)ethyl)- $1 H$-indole-2-carboxamide

(123),
(5-chloro-1-(4-fluorobenzyl)-1H-indol-2-yl) (4-(4-methoxybenzyl)piperazin-1-yl)methadone (124) and (5-chloro1-(4-chlorobenzyl)-1H-indol-2-yl)(4-(4-chlorobenzyl) piperazin-1-yl)methadone (125) were exhibited the highest selectivity as anti-inflammatory agents. Furthermore, potent compounds (122-124) marked potential in-vitro COX-2 inhibitory as compared to the reference celecoxib. In addition, the results showed that compounds (123 and 124) have no significant cytotoxicity on normal cells. 


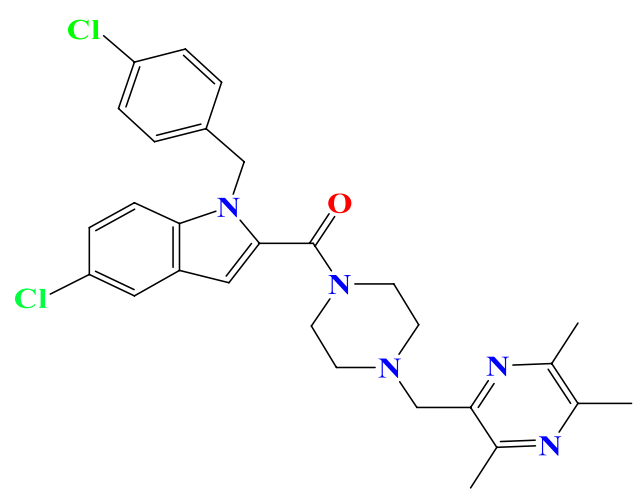

(122)

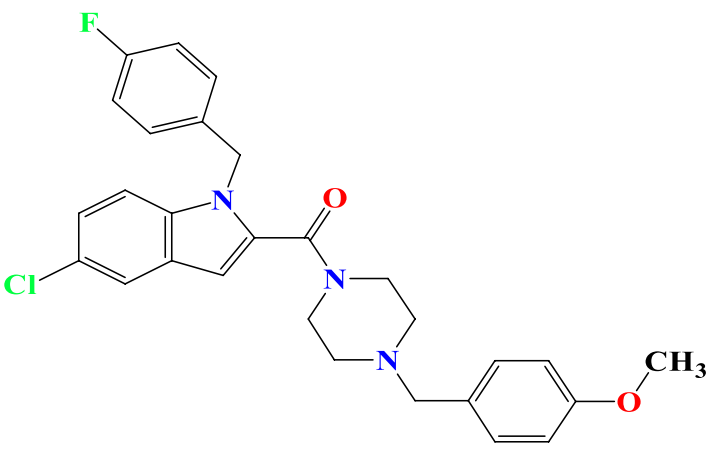

(124)

\section{An overview of quinoline as possible therapeutic candidates}

The literature survey reveals that day by day in the whole world health problems are increasing and in this view the discovery of new therapeutics is highly essential [168-170]. Also, a majority of heterocyclic compounds are commonly distributed both in natural products like alkaloids and in various aspects of the synthetic chemotherapy fields are playing a vital role in our life [171]. In particularly, nitrogen-based heterocyclic aromatic compound like quinoline attracted tremendous attention over the past 200 years [172]. Quinoline is a naturally occurring compound in carbon tar and also can be detected in tobacco smoke, petroleum refining pollution, coal, shale oil extraction and wood processing [173]. Further, it is used as a solvent for resins and terpenes which are used in paint manufacturing as well as for metallic<smiles>COc1ccc2[nH]cc(CCNC(=O)c3cc4cc(Cl)ccc4n3Cc3ccc(F)cc3)c2c1</smiles>

(123)<smiles>O=C(c1cc2cc(Cl)ccc2n1Cc1ccc(Cl)cc1)N1CCN(Cc2ccc(Cl)cc2)CC1</smiles>

(125)

corrosion inhibition, due to its combination of high electron density [174]. There are a number of natural products (126-129) with quinoline skeleton isolated from different plant species which are used as a medicine or employed as a lead molecule for the development of newer and potent molecules [175]. Furthermore, several quinoline derivatives have been found to be used as agrochemicals as well as in the processing of dyes, food colorants and $\mathrm{pH}$ indicators as well as in the synthesis of other organic substances [176]. Moreover, quinolines and its derivatives can also emerge as potential therapeutic agents in the treatment of cancer, heart failure and inflammatory diseases [177, 178]. Also, it represents an attractive class of compounds possessing biological activities such as anti-convulsant [179], analgesic [180], anti-bacterial [181], anti-fungal [182], anti-malarial [183] and so on. 
<smiles>CCCc1cc(OC)c2ccccc2n1</smiles>

(126)<smiles>C/C=C/c1ccc2ccccc2n1</smiles>

(128)<smiles>C/C=C/c1cc(OC)c2ccccc2n1</smiles>

(127)<smiles>CCNCCNc1cc(OC)cc2c(C)ccnc12</smiles>

(129)

\section{Introduction to synthesis of quinoline and its derivatives}

Quinoline is a nitrogenous bicyclic heterocyclic belonging to the class of organic compounds with the molecular formula of $\mathrm{C}_{9} \mathrm{H}_{7} \mathrm{~N}$ [184]. The quinoline moiety consists of a benzene ring fused into a pyrimidine to form benzo[b]pyridine. It exists as a colorless liquid, slightly soluble in water and used as an anti-corrosive substance [185]. There are many methods associated with quinoline synthesis involving Skraup synthesis, Doebner-miller Ring synthesis, Povarov reaction, Friedlander synthesis, Conrad-Limpach reaction and Combes synthesis Fig. 5. For example, Skraup quinoline synthesis is the best chemical reaction used to synthesis quinoline from heated primary aromatic amines with glycerol, and an oxidizing agent such as nitrobenzene in concentrated sulfuric acid [186].

Recently novel series of quinoline derivative was synthesized by Prasad et al. using multi-component reaction, starting with aniline (130), 2-nitro benzaldehyde (131) and propargyl alcohol (132) in the presence of copper bromide to get (2-(2-nitrophenyl)quinolin-4 yl)methanol (133) as shown in Scheme 21.

Then intermediate compound (133) subjected to a series of reactions to get the final two series of quinolines derivatives (137a-b) and (138a-b). Finally, these compounds were characterized by using NMR and mass spectra as shown in Scheme 22 [187].

A convenient and eco-friendly protocol for the synthesis of polysubstituted quinoline analogs (141) was achieved using propylphosphonic anhydride $\left(\mathrm{T}_{3} \mathrm{P}\right)$ as a mild water scavenger catalyst with minimizing reaction times and excellent yields as shown in Scheme 23 [172].

Quinoline-based Schiff base derivatives (144) have been introduced by Muhammad Taha et al. [188] by refluxing methanolic mixture of methyl quinoline-6-carboxylate (142) and hydrazine hydrate for $6 \mathrm{~h}$ to obtain quinoline-6-carbohydarzide (143). The intermediate (143) was then refluxed for $3 \mathrm{~h}$ with various aromatic aldehydes in the presence of 5-6 drops of glacial acetic acid to obtain quinoline derivatives (Z)- $N$ '-ethylidenequinoline-6-carbohydrazide (144) as shown in Scheme 24.

\section{Pharmaceutical aspects of quinoline derivatives}

Quinoline derivatives as anti-diabetic II agents The quinoline Schiff base derivatives (144) were evaluated against diabetic-II activity, it was found that compounds $(E)-N^{\prime}$ (2,5-dihydroxybenzylidene)quinoline-6-carbohydrazide (145), (E)- $N$ '-(2,3-dihydroxybenzylidene)quinoline-6-carbohydrazid (146), (E)-N'-(2,4-dihydroxy benzylidene) 
quinoline-6-carbohydrazide (147), (E)- $N$ '-(3,4-dihydroxybenzylidene)quinoline-6-carbohydrazide (148), (E)- $N$ '(3-hydroxy-4-methoxybenzylidene)quinoline-6-carbo hydrazide (149), (E)- $N$ '-(2-fluorobenzylidene)quinoline6-carbohydrazide (150) and (E)- $N^{\prime}$-(2-hydroxybenzylidene) quinoline-6-carbohydrazide (151) displayed most potent anti-diabetic II activity. Further, derivative (148) was found as a good inhibitor against $\alpha$-glucosidase in comparison with the reference drug [188].<smiles>[R]c1cc(C(=O)O)c2ccccc2n1</smiles>

(2) Doebner<smiles>c1ccc2ncccc2c1</smiles>

(1) Skraup<smiles>[R1]C=CC(=O)OCc1cc([R1])c2ccccc2n1</smiles>

(3) Doebner-Von Miller<smiles>CC(C)C(=O)O</smiles>

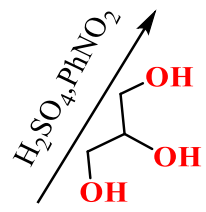

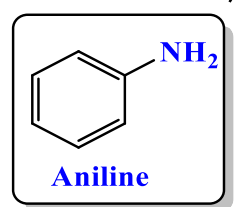

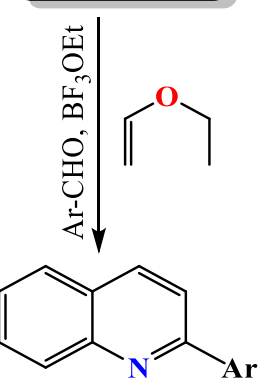

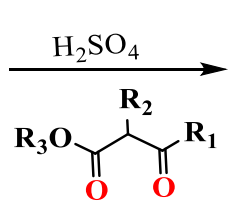

$\mathrm{R}=$ Different alkyl and aryl groups

(4) Povarov

Fig. 5 Some quinoline synthesis methods: (1) Skraup reaction, (2) Doebner reaction, (3) Doebner-Von Miller reaction, (4) Povarov reaction and (5) Conrad-Limpach reaction

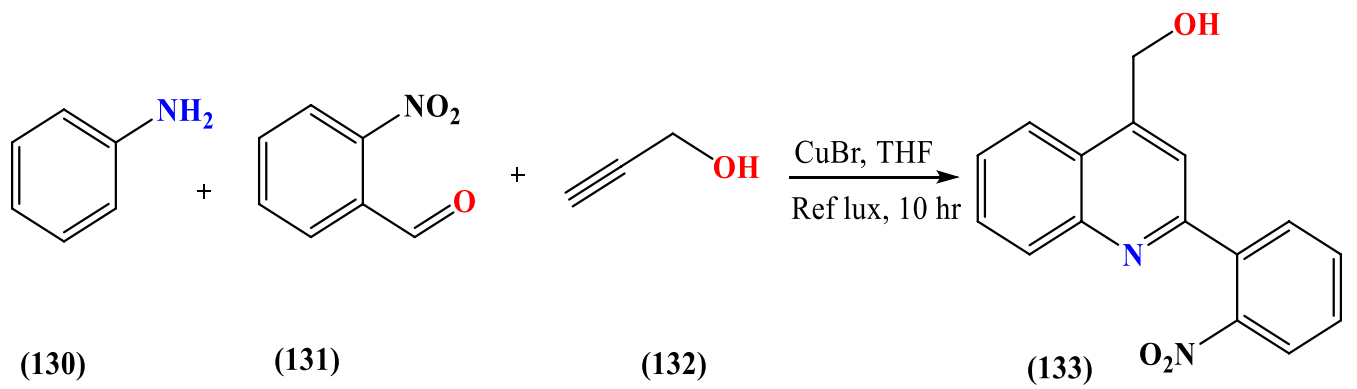

Scheme 21 Synthesis of nitrophenyl quinolin 


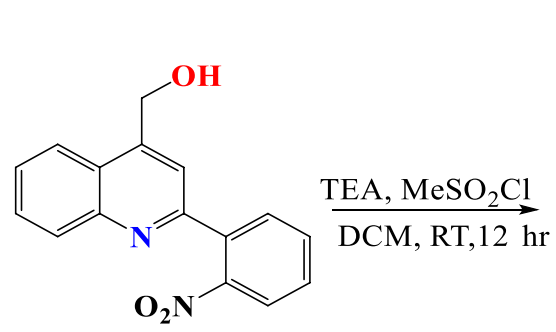

(133)<smiles>CS(=O)(=O)OCc1cc(-c2ccccc2[N+](=O)[O-])nc2ccccc12</smiles>

$\frac{\text { TEA,1-Boc, Piperazine }}{\mathrm{ACN}, \mathrm{RT}, 11 \mathrm{hr}}$

(134)<smiles>[R]C(=O)Nc1ccccc1-c1cc(CN2CCNCC2)c2ccccc2n1</smiles>

(138a-b)<smiles>[R]C(=O)Nc1ccccc1-c1cc(CN2CCN(C(C)(C)C)CC2)c2ccccc2n1</smiles>

(137a-b)

$\mathrm{Et}_{3} \mathrm{~N}, \mathrm{DCM}, \mathrm{RT}, 2 \mathrm{hr}$<smiles>[R]C(=O)Cl</smiles>

b: $\mathbf{R}=$<smiles>[Y]C(=O)c1ccc([R]#[R])cc1</smiles>

Scheme 22 Synthesis of two series of new quinolines derivatives

Scheme 23 Synthesis of poly-

substituted quinoline analogs<smiles>Nc1ccc(Cl)cc1C(=O)c1ccccc1</smiles>

(139)<smiles>CCCP1(=O)OP(=O)([In])OP(=O)(C(C)C)O1</smiles><smiles>CC(C)(C)OC(=O)N1CCN(Cc2cc(-c3ccccc3[N+](=O)[O-])nc3ccccc23)CC1</smiles>

(135)

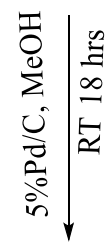<smiles>CCCNc1ccccc1-c1cc(CN2CCN(C(C)(C)C)CC2)c2ccccc2n1</smiles>

(136) 


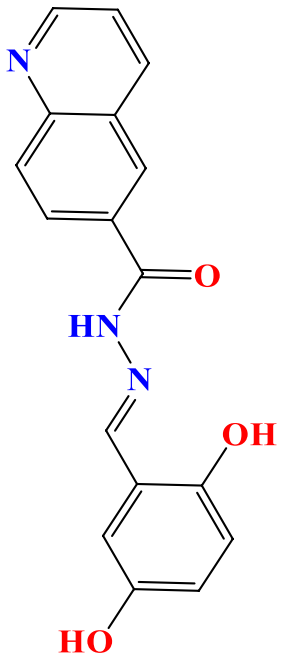

(145)

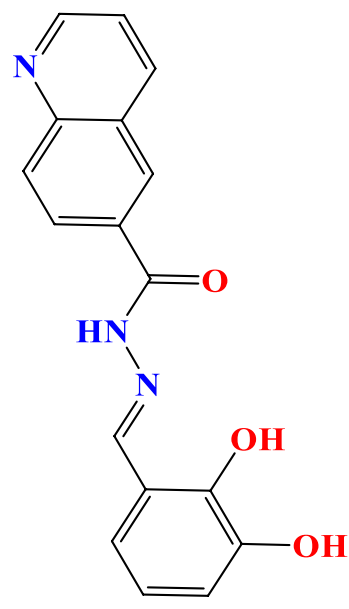

(146)
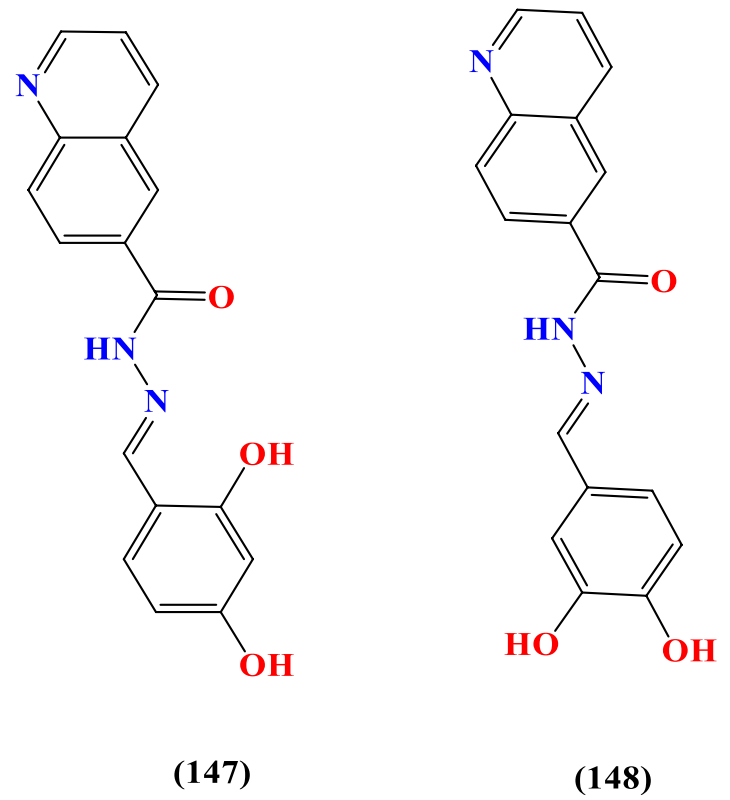

(148)

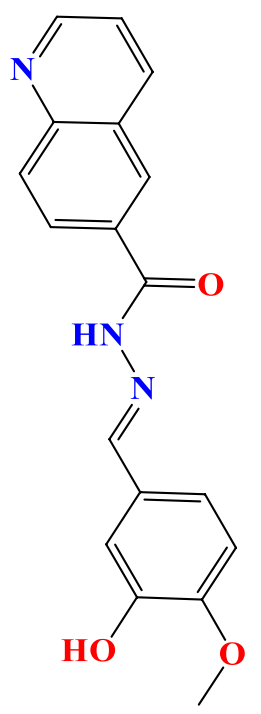

(149)

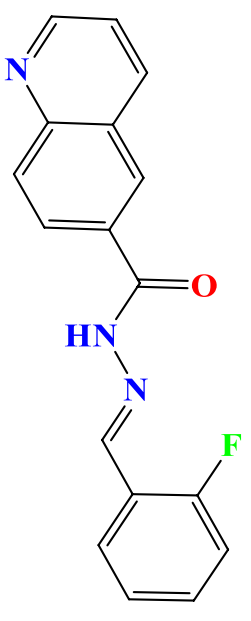

(150)

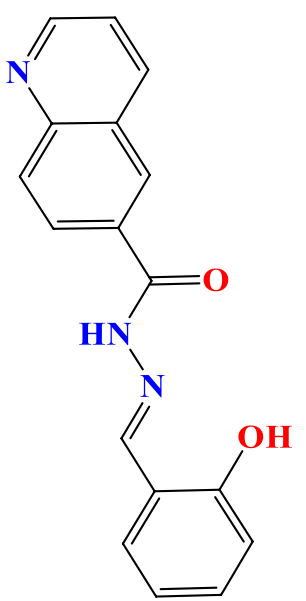

(151)
Quinoline derivatives as anti-cancer agents In 2018, a group of researcher synthesized a variety of substituted quinoline derivatives as anti-cancer agent and evaluated in-vitro anti-cancer activity against different cell lines. Compounds 6-bromo-5-nitroquinoline (152) and 6,8-diphenylquinoline
(153) showed the highest anti-proliferative activity as compared to the 5-fluorouracil (5-FU) as reference drug. Furthermore, compound (152) has been detected as a potential apoptotic activity inducer [189]. 


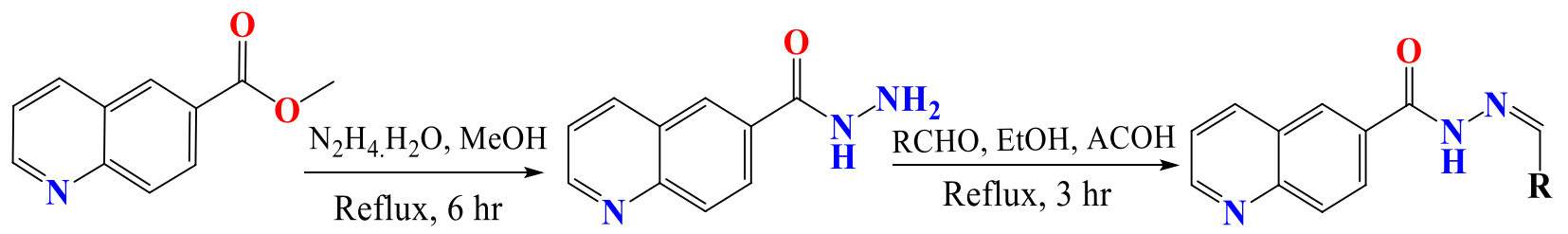

(142)

(143)

(144)

Scheme 24 Synthesis of ethylidenequinoline carbohydrazide derivatives<smiles>O=[N+]([O-])c1c(Br)ccc2ncccc12</smiles>

(152)<smiles>c1ccc(-c2cc(-c3ccccc3)c3ncccc3c2)cc1</smiles>

(153) that of standard. In addition, anti-microbial screening exhibited that these compounds (154-157) showed an interesting activity against both gram-positive and negative bacteria.<smiles>CC(=O)/C(=N/Nc1ccc(Br)cc1)Nc1cccc2cccnc12</smiles>

(154)<smiles>CC(=O)/C(=N/Nc1ccc(F)cc1)Nc1cccc2cccnc12</smiles>

(155)<smiles></smiles>

(156)<smiles>CC(=O)/C(=N/Nc1ccc([N+](=O)[O-])cc1)Nc1cccc2cccnc12</smiles>

(157)
Quinoline derivatives as anti-oxidant, anti-inflammatory and anti-microbial agents In the year 2020, synthesis of four azo-imine quinoline derivatives (154-157) were established by Khaoula et al. [190] In this study, azo-imine quinolines were designed, synthesized and evaluated against anti-oxidant, anti-inflammatory and anti-microbial activities. The results displayed that compounds (154 and $\mathbf{1 5 5}$ ) considered as potential anti-oxidants. Further, the same compounds were revealed potent anti-inflammatory activity similar to
Quinoline derivatives as anti-tubercular agents Interestingly, the efficient protocol of a novel quinoline derivatives synthesis has been developed by Rajkumar et al. [191] and also evaluated them against anti-tubercular activity. Molecules with amide linkage showed good inhibition activity as compared to their ether analogs. Among all novel series, compounds (158-162) exhibited significant activity against M.tuberculosis H37Rv. 
<smiles>COc1ccc(C(=O)Cn2cc(CNC(=O)c3cc4cc(OC)ccc4nc3Cl)nn2)cc1</smiles>

(158)

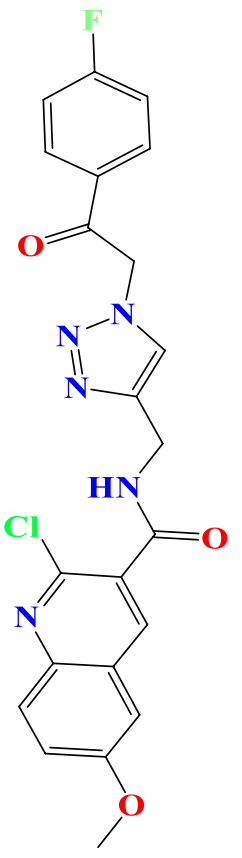

(159)<smiles>COc1ccc(Cn2cc(CNC(=O)c3cc4cc(OC)ccc4nc3Cl)nn2)cc1</smiles>

(160)<smiles>COc1ccc2nc(Cl)c(C(=O)NCc3cn(Cc4ccccc4)nn3)cc2c1</smiles>

(161)<smiles>COc1ccc2nc(Cl)c(C(=O)NCc3cn(Cc4ccc(C#N)cc4)nn3)cc2c1</smiles>

(162)

\section{Conclusion}

The current review strongly described the various synthetic methods and biological activities of phenoxy acetamide and its derivatives (Chalcone, Indole and Quinoline), due to various their greater influence and relevance in the pharmaceutical field of chemistry. The need has always been and will still continue to survive in the medical domain for new drugs with different biological effects. In the available literature, our efforts focus more on a study of the biological impact of phenoxy acetamide and its derivatives. Phenoxy acetamide and its derivatives are significant pharmacophores with distinct biological activities, and several different derivatives of phenoxy acetamide already have been used for therapeutic applications.

The above literature review demonstrates that phenoxy acetamide and its derivatives are pharmacologically very powerful, and thus, their design and synthesis is the future area of research. Furthermore, it has been shown that the structural modification of the different positions of the basic 
molecules enables enhancing the pharmacological characteristic. Phenoxy acetamide, chalcone, indole and quinoline scaffolds have gained and expanded importance in the field of medicinal chemistry by exhibiting different biological activities such as anti-convulsant, analgesic, anti-bacterial, anti-inflammatory, anti-cancer and anti-fungal, etc. This review significantly enhanced the awareness of such scaffolds and offered new methods to develop efficient pharmacological properties for new derivatives. Therefore, it is recommended to researchers in the future to pay more attention to such compounds that have significantly contributed to the pharmaceutical area which we expect to play a key role in light of developing new synthesis methods in order to enhance their applications.

Acknowledgements Fares Hezam Al-Ostoot is thankful to the government of Yemen and Al-Baydha University, Yemen, for providing financial assistance under the teacher's fellowship and also thankful to the University of Mysore, Mysore, India. Zabiulla is thankful to the St. Philomena's College Bannimantap, Mysuru, Karnataka, India. Shaukath Ara Khanum thankfully acknowledges the financial support provided by VGST, Bangalore, under CISEE Program [Project sanction order: No. VGST/CISEE/282/2012-13].

\section{Compliance with ethical standards}

Conflict of interest The authors declare that there are no conflicts of interest.

\section{References}

1. A. Gerais, Quim. Nova. 24, 153-155 (2001)

2. P. Krogsgaard-Larsen, R. Pelliciari, N. De Souza, H. Timmerman, D.J. Triggle, C.A. van Boeckel, J. Wasley, Drug Dev Res. 66, 1-8 (2005)

3. M.K. Gilson, T. Liu, M. Baitaluk, G. Nicola, L. Hwang, J. Chong, Nucl. Acids Res. 44, 1045-1053 (2016)

4. M.F. Khan, M.J. Deimling, A. Philip, Am. J. Pharm. Educ. 75, 1-10 (2011)

5. A.K. Ghosh, M. Brindisi, J. Med. Chem. 63, 2751-2788 (2019)

6. Y. Hu, D. Stumpfe, J. Bajorath, J. Med. Chem. 59, 4062-4076 (2016)

7. J.B. Brown, J. Bajorath, Future Med. Chem. 11, 1-3 (2019)

8. V.J. Hruby, J. Organ. Chem. 74, 9245-9264 (2009)

9. R. Hajar, Heart Views 16, 43-45 (2015)

10. C.M. Puchalski, Bayl. Univ. Med. Cent. 14, 352-357 (2001)

11. M. Ekor, Front. Pharmacol. 4, 1-10 (2014)

12. M.S. Bulter, Nat. Prod. Rep. 22, 162-195 (2005)

13. M. Atif, I. Malik, D. Dawoud, A. Gilani, N. Ahmed, Z.U. Babar, Enc. Pharm. Pract. Clin. Pharm. 1, 239-249 (2019)

14. M. Iskar, G. Zeller, X.M. Zhao, V. van Noort, P. Bork, Curr. Opin. Biotechnol. 23, 609-616 (2012)

15. S. Mathur, C. Hoskins, Biomed. Rep. 6, 612-614 (2017)

16. J.P. Fernandes, Am. J. Pharm. Educ. 82, 106-114 (2018)

17. K.I. Kaitin, J.A. DiMasi, Clin. Pharm. Therap. 89, 183-218 (2011)

18. M. Batool, B. Ahmad, S. Choi, Int. J. Mol. Sci. 20, 2783 (2019)

19. G. Schneider, D.E. Clark, Angew. Chem. Int. Ed. 58, 1079210803 (2019)
20. H.S. Chan, H. Shan, T. Dahoun, H. Vogel, S. Yuan, Trends Pharmacol. Sci. 40, 592-604 (2019)

21. G. Mariappan, A. Kumari, Computer Applications in Drug Discovery and Development (2019), pp. 101-126

22. I.B. Campbell, S.J. Macdonald, P.A. Procopiou, Drug Discov. Today 23, 219-234 (2018)

23. A.G. Atanasov, B. Waltenberger, E.M. Pferschy-Wenzig, T. Linder, C. Wawrosch, P. Uhrin, V. Temml, L. Wang, S. Schwaiger, E.H. Heiss, J.M. Rollinger, Biotechnol. Adv. 33, 1582-1614 (2015)

24. K.R. Campos, P.J. Coleman, J.C. Alvarez, S.D. Dreher, R.M. Garbaccio, N.K. Terrett, R.D. Tillyer, M.D. Truppo, E.R. Parmee, Science 363, 6424 (2019)

25. J.P. Hughes, S. Rees, S.B. Kalindjian, K.L. Philpott, Br. J. Pharmacol. 162, 1239-1249 (2011)

26. S. Pegler, J. Underhill, Obstet. Gynecol. 116, 1405-1409 (2010)

27. V. Khanna, S. Ranganathan, BMC Bioinf. 10, S10 (2009)

28. W.H. Brooks, W.C. Guida, K.G. Daniel, Curr. Trends Med. Chem. 11, 760-770 (2011)

29. F.H. Al-Ostoot, Y.H. Mohammed, A.N. Zabiulla, S.A. Khanum, J. Appl. Pharm. Sci. 9, 042-049 (2019)

30. A. Alam, U. Farooq, R. Singh, V.P. Dubey, S. Kumar, R. Kumari, K. Kumar, B.D. Naik, KL. Dhar, J. Toxicol. 2, 1-5 (2018)

31. A. Karpozilos, N. Pavlidis, Eur. J. Cancer 40, 2033-2040 (2004)

32. S.L. Smith, CMAJ 189, 321-322 (2017)

33. L. Falzone, S. Salomone, M. Libra, Front. Pharmacol. 9, 1300 (2018)

34. K. Röhrl, M.G. Guren, M.C. Småstuen, T. Rustøen, Support. Care Cancer 27, 3007-3017 (2019)

35. M.S. Ricci, W.X. Zong, Oncologist 11, 342 (2006)

36. V. Schirrmacher, Int. J. Oncol. 54, 407-419 (2019)

37. M.O. Palumbo, P. Kavan, W. Miller, L. Panasci, S. Assouline, N. Johnson, V. Cohen, F. Patenaude, M. Pollak, R.T. Jagoe, G. Batist, Front. Pharmacol. 4, 57 (2013)

38. E. Bolesta, L.W. Pfannenstiel, A. Demelash, M.L. Lesniewski, M. Tobin, S.E. Schlanger, S.C. Nallar, J.C. Papadimitriou, D.V. Kalvakolanu, B.R. Gastman, Mol. Cell. Biol. 32, 1879-1892 (2012)

39. I. Altun, A. Sonkaya, Iran. J. Public Health 47, 1218-1219 (2018)

40. S. Begum, K. Bharathi, K.V. Prasad, Int. J. Pharm. Pharm. Sci. 8, 66-71 (2016)

41. S. Kumar, S. Kumar, S.R. Hashim, J. Drug Deliv. Ther. 9, 402405 (2019)

42. Y. Huang, L. Xiao, F. Li, M. Xiao, D. Lin, X. Long, Z. Wu, Molecules 23, 2313 (2018)

43. E. Leyva, L.I. López, R.F. de la Cruz, C.G. Espinosa-González, Res. Chem. Intermed. 43, 1813-1827 (2017)

44. M.P. Polat, H.Y. Yenilmez, A. Koca, A. Altındal, Z.A. Bayır, Dyes Pigm. 156, 267-275 (2018)

45. K. Ohta, K. Minami, H. Yoshikawa, Y. Ishida, Synthesis and herbicidal activity of phenoxypropionic acid derivatives with imidazo [1, 2-a] pyridine moiety. Biosci. Biotechnol. Biochem. 57, 844-1848 (1993)

46. A.A. Siddiqui, M.A. Ali, Bioorg. Med. Chem. Lett. 16, 45714574 (2006)

47. A. Nakhostin, S. Mirseyyedhosein, M. Toolabi, P. Khodabakhsh, H. Aghamiri, S. Ghaffari, H. Shafaroodi, A. Shayesteh, M. Amini, A. Shafiee, L. Navidpour, Med. Chem. Res. 25, 2220 2236 (2016)

48. M.L. Bolognesi, F. Lizzi, R. Perozzo, R. Brun, A. Cavalli, Bioorg. Med. Chem. Lett. 18, 2272-2276 (2008)

49. M. Shahar Yar, M.A. Bakht, A.A. Siddiqui, M.M. Abdullah, E. De Clercq, J. Enzyme Inhib. Med. Chem. 24, 876-882 (2009)

50. U.R. Samel, W. Kohler, A.O. Gamer, U. Keuser, S.T. Yang, Y. Jin, M. Lin, Z. Wang, J.H. Teles, Ullmann's Encycl. Ind. Chem. 15, 1-20 (2000) 
51. S.A. Khanum, N.F. Khanum, M. Shashikanth, Bioorg. Med. Chem. Lett. 18, 4597-4601 (2008)

52. Y.H. Mohammed, V.H. Malojirao, P. Thirusangu, M. Al-Ghorbani, B.T. Prabhakar, S.A. Khanum, Eur. J. Med. Chem. 143, 1826-1839 (2018)

53. Y.H. Mohammed, P. Thirusangu, Zabiulla, V. Vigneshwaran, B.T. Prabhakar, S.A. Khanum, Biomed. Pharmacother. 95, 375-386 (2017)

54. G. Turan-Zitouni, L. Yurttaş, Z.A. Kaplancıklı, Ö.D. Can, Ü.D. Özkay, Med. Chem. Res. 24, 2406-2416 (2015)

55. P. Rani, D. Pal, R.R. Hegde, S.R. Hashim, BioMed Res. Int. 2014, 1-9 (2014)

56. R. Sheng, X. Lin, J. Li, Y. Jiang, Z. Shang, Y. Hu, Design, synthesis, and evaluation of 2-phenoxy-indan-1-one derivatives as acetylcholinesterase inhibitors. Bioorg. Med. Chem. Lett. 15, 3834-3837 (2005)

57. S.M. Yar, A.A. Siddiqui, A.M. Ali, J. Serb. Chem. Soc. 72, 5-11 (2007)

58. T. Prashanth, V.L. Ranganatha, P. Naveen, H.D. Gurupadaswamy, A.B. Begum, M. Al-Ghorbani, S.A. Khanum, Free Radic. Antioxid. 3, S50-S54 (2013)

59. H. Srinivasan, V.K. Sharma, V.G. Sakai, J.P. Embs, R. Mukhopadhyay, S. Mitra, J. Phys. Chem. B. 124, 1509-1520 (2020)

60. G.H. Coleman, A.M. Alvarado, Acetamide Org. Synth. 3, 3 (2003)

61. X. Xia, Curr. Trends Med. Chem. 17, 1709-1726 (2017)

62. Y. Gull, N. Rasool, M. Noreen, A.A. Altaf, S.G. Musharraf, M. Zubair, F.U. Nasim, A. Yaqoob, V. DeFeo, M. Zia-Ul-Haq, Molecules 21, 266 (2016)

63. A.S. Yusov, S.V. Chashchina, A.G. Mikhailovskii, I.P. Rudakova, Pharm. Chem. J. 53, 35-39 (2019)

64. S. Ölgen, F. Bakar, S. Aydin, D. Nebioğlu, S. Nebioğlu, J. Enzyme Inhib. Med. Chem. 28, 58-64 (2013)

65. J. Khazir, B.A. Mir, G. Chashoo, T. Maqbool, D. Riley, L. Pilcher, J. Heterocycl. Chem. 57, 1306-1318 (2020)

66. H.I. Severina, O.O. Skupa, N.I. Voloshchuk, V.A. Georgiyants, J. Appl. Pharm. Sci. 10, 001-008 (2020)

67. A.G. Mikhailovskii, E.S. Pogorelova, N.N. Pershina, R.R. Makhmudov, V.V. Novikova, Pharm. Chem. J. 53, 1-5 (2020)

68. A.F. Borsoi, J.D. Paz, B.L. Abbadi, F.S. Macchi, N. Sperotto, K. Pissinate, R.S. Rambo, A.S. Ramos, D. Machado, M. Viveiros, C.V. Bizarro, Eur. J. Med. Chem. 192, 112179 (2020)

69. S.J. Mary, M.U. Siddique, S. Pradhan, V. Jayaprakash, C. James, Spectrochim. Acta, Part A 244, 118825 (2020)

70. D. Bhavsar, J. Trivedi, S. Parekh, M. Savant, S. Thakrar, A. Bavishi, A. Radadiya, H. Vala, J. Lunagariya, M. Parmar, L. Paresh, Bioorg. Med. Chem. Lett. 21, 3443-3446 (2011)

71. G. Sharma, S. Anthal, D.V. Geetha, F.H. Al-Ostoot, Y.H.E. Mohammed, S.A. Khanum, M.A. Sridhar, R. Kant, Mol. Cryst. Liq. Cryst. 675, 85-95 (2018)

72. A. Caruso, S. Marzocco, B. Nicolaus, C. Palladino, A. Pinto, A. Popolo, M.S. Sinicropi, G. Tommonaro, C. Saturnino, Molecules 15, 2028-2038 (2010)

73. S.A. Katke, S.V. Amrutkar, R.J. Bhor, M.V. Khairnar, Int. J. Pharma Sci. Res. 2, 148-156 (2011)

74. M.L. Barbosa, G.M. Melo, Y.K. Silva, O. Lopes Rde, E.T. Souza, A.C. Queiroz, S. Smaniotto, M.S. Alexandre-Moreira, E.J. Barreiro, L.M. Lima, Eur. J. Med. Chem. 44, 3612-3620 (2009)

75. J. Khazir, B.A. Mir, M. Pandita, L. Pilcher, D. Riley, G. Chashoo, Med. Chem. Res. 29, 916-925 (2020)

76. S.M. Shelke, S.H. Bhosale, Bioorg. Med. Chem. Lett. 20, 46614664 (2010)

77. A.K. Shakya, M. Kamal, V.M. Balaramnavar, S.K. Bardaweel, R.R. Naik, A.K. Saxena, H.H. Siddiqui, Acta Pharm. 66, 353372 (2016)
78. R.R. Shinde, D. Gaikwad, M. Farooqui, J. Heterocycl. Chem. 57, 3907-3917 (2020)

79. C. Zhuang, W. Zhang, C. Sheng, W. Zhang, C. Xing, Z. Miao, Chem. Rev. 117, 7762-7810 (2017)

80. P. Elamathi, G. Chandrasekar, M.M. Balamurali, J. Porous Mater. 27, 817-829 (2020)

81. B.Z. Kurt, N.O. Kandas, A. Dag, F. Sonmez, M. Kucukislamoglu, Arab. J. Chem. 13, 1119-1120 (2020)

82. M.B. Dos Santos, D. Bertholin Anselmo, J.G. de Oliveira, B.V. Jardim-Perassi, D. Alves Monteiro, G. Silva, E. Gomes, A. Lucia Fachin, M. Marins, D.A. de Campos Zuccari, L. Octavio Regasini, J. Enzyme Inhib. Med. Chem. 34, 1093-1099 (2019)

83. L. Wang, X. Yang, Y. Zhang, R. Chen, Y. Cui, Q. Wang, J. Nat. Prod. 82, 2761-2767 (2019)

84. C.Y. Hsieh, P.W. Ko, Y.J. Chang, M. Kapoor, Y.C. Liang, H.L. Chu, H.H. Lin, J.C. Horng, M.H. Hsu, Molecules 24, 3259 (2019)

85. S. Pola, K.K. Banoth, M. Sankaranarayanan, R. Ummani, A. Garlapati, Med. Chem. Res. 29, 1819-1835 (2020)

86. M. Mellado, L. Espinoza, A. Madrid, J. Mella, E. Chávez-Weisser, K. Diaz, M. Cuellar, Mol. Divers. 24, 603-615 (2019)

87. Y.A. Vásquez-Martínez, M.E. Osorio, D.A. San Martín, M.A. Carvajal, A.P. Vergara, E. Sanchez, M. Raimondi, S.A. Zacchino, C. Mascayano, C. Torrent, F. Cabezas, J. Braz. Chem. Soc. 30, 286-304 (2019)

88. M. Ortalli, A. Ilari, G. Colotti, I. De Ionna, T. Battista, A. Bisi, S. Gobbi, A. Rampa, R.M. Di Martino, G.A. Gentilomi, S. Varani, Eur. J. Med. Chem. 152, 527-541 (2018)

89. T.T. Dao, H.J. Linthorst, R. Verpoorte, Phytochem. Rev. 10, 397-412 (2011)

90. H.P. Ávila, E.D. Smânia, F. Delle Monache, A.S. Júnior, Bioorg. Med. Chem. 16, 9790-9794 (2008)

91. S.M. Kumar, A.O. Hezam, B.C. Manjunath, V.R. Shamprasad, Y.H. Mohammed, N. Mahesh, A.K. Shaukath, N.K. Lokanath, K. Byrappa, J. Mol. Struct. 1156, 216-223 (2018)

92. S. Burmaoglu, A.O. Yilmaz, M.F. Polat, R. Kaya, I. Gulcin, O. Algul, Bioorg. Chem. 85, 191-197 (2019)

93. S. Farooq, Z. Ngaini, Curr. Organocatal. 6, 184-192 (2019)

94. P. Gupta, A. Mahajan, Environ. Chem. Lett. 17, 879-895 (2019)

95. M. Chtourou, R. Abdelhédi, M.H. Frikha, M. Trabelsi, Ultrason. Sonochem. 17, 246-249 (2010)

96. F. Ramirez, S. Dershowitz, Org. Chem. 22, 41-45 (1957)

97. L.F. Castaño, V. Cuartas, A. Bernal, A. Insuasty, J. Guzman, O. Vidal, V. Rubio, G. Puerto, P. Lukáč, V. Vimberg, G. BalíkováNovtoná, Eur. J. Med. Chem. 176, 50-60 (2019)

98. Y. Wang, W. Zhang, J. Dong, J. Gao, Bioorg. Chem. 95, 103530 (2020)

99. Z.H. Huang, L.Q. Yin, L.P. Guan, Z.H. Li, C. Tan, Bioorg. Med. Chem. Lett. 30, 127173 (2020)

100. M. Xu, P. Wu, F. Shen, J. Ji, K.P. Rakesh, Bioorg. Chem. 91, $103133(2019)$

101. A. Shaik, R.R. Bhandare, K. Palleapati, S. Nissankararao, V. Kancharlapalli, S. Shaik, Molecules 25, 1047 (2020)

102. M. Hossain, A.K. Nanda, Science 6, 83-94 (2018)

103. A.M. Eissa, R. El-Sayed, J. Heterocycl. Chem. 43, 1161-1168 (2006)

104. TH. Altel, RA. El-Awady, S. Vunnam, FI. Al-Marzooq, U.S. Patent 10,526,343 (2020)

105. M. Asif, Int. J. Bioorg. Chem. 2, 146-152 (2017)

106. R.P. Singh, H. Gao, D.T. Meshri, M.S. Jean'ne, Struct. Bond 125, 35-83 (2007)

107. B. Eftekhari-Sis, M. Zirak, A. Akbari, Chem. Rev. 113, 29583043 (2013)

108. N. Kerru, S. Maddila, S.B. Jonnalagadda, Curr. Org. Chem. 23, 3154-3190 (2019)

109. Y. Ju, R.S. Varma, J. Org. Chem. 71, 135-141 (2006) 
110. D. Zárate-Zárate, R. Aguilar, R.I. Hernández-Benitez, E.M. Labarrios, F. Delgado, J. Tamariz, Tetrahedron 71, 6961-6978 (2015)

111. P.D. Leeson, B. Springthorpe, Nat. Rev. Drug Discov. 6, 881-890 (2007)

112. K. Kumara, F.H. Al-Ostoot, Y.H. Mohammed, S.A. Khanum, N.K. Lokanath, Chem. Data Collect. 20, 100195 (2019)

113. Z. Martins, Life 8, 28 (2018)

114. I. Chitrakar, D.M. Kim-Holzapfel, W. Zhou, J.B. French, J. Struct. Biol. 197, 354-364 (2017)

115. K.A. Laptinskiy, E.N. Vervald, A.N. Bokarev, S.A. Burikov, M.D. Torelli, O.A. Shenderova, I.L. Plastun, T.A. Dolenko, J. Phys. Chem. C. 122, 11066-11075 (2018)

116. R.M. Tikhov, N.Y. Kuznetsov, Org. Biomol. Chem. 18, 2793$2812(2020)$

117. S. Depauw, M. Lambert, S. Jambon, A. Paul, P. Peixoto, R. Nhili, L. Marongiu, M. Figeac, C. Dassi, C. Paul-Constant, B. Billoré, J. Med. Chem. 62, 1306-1329 (2019)

118. F.Q. Shen, L. Shi, Z.F. Wang, C.R. Wang, J.J. Chen, Y. Liu, H.Y. Qiu, H.L. Zhu, Bioorg. Med. Chem. 27, 3813-3824 (2019)

119. Y. Wan, Y. Li, C. Yan, M. Yan, Z. Tang, Eur. J. Med. Chem. 183, 111691 (2019)

120. W. Li, W. Shuai, H. Sun, F. Xu, Y. Bi, J. Xu, C. Ma, H. Yao, Z. Zhu, S. Xu, Eur. J. Med. Chem. 163, 428-442 (2019)

121. P. Gao, L. Wang, L. Zhao, Q.Y. Zhang, K.W. Zeng, M.B. Zhao, Y. Jiang, P.F. Tu, X.Y. Guo, Phytochemistry 172, 112260 (2020)

122. C. Luchese, A. Barth, G.P. da Costa, D. Alves, D.L. Novo, M.F. Mesko, E.A. Wilhelm, Exp. Gerontol. 130, 110804 (2020)

123. R. Wang, Y. Chen, B. Yang, S. Yu, X. Zhao, C. Zhang, C. Hao, D. Zhao, M. Cheng, Bioorg. Chem. 94, 103474 (2020)

124. G. Wang, J. Wan, Y. Hu, X. Wu, M. Prhavc, N. Dyatkina, V.K. Rajwanshi, D.B. Smith, A. Jekle, A. Kinkade, J.A. Symons, J. Med. Chem. 59, 4611-4624 (2016)

125. S. Zhang, Z. Xu, C. Gao, Q.C. Ren, L. Chang, Z.S. Lv, L.S. Feng, Eur. J. Med. Chem. 138, 501-513 (2017)

126. J. Zhang, S. Wang, Y. Ba, Z. Xu, Eur. J. Med. Chem. 74, 1-8 (2019)

127. M. Adib, F. Peytam, R. Shourgeshty, M. Mohammadi-Khanaposhtani, M. Jahani, S. Imanparast, M.A. Faramarzi, B. Larijani, A.A. Moghadamnia, E.N. Esfahani, F. Bandarian, Bioorg. Med. Chem. Lett. 29, 713-718 (2019)

128. Y. Okano, N. Saito-Tarashima, M. Kurosawa, A. Iwabu, M. Ota, T. Watanabe, F. Kato, T. Hishiki, M. Fujimuro, N. Minakawa, Bioorg. Med. Chem. 27, 2181-2186 (2019)

129. N. Polish, M. Nesterkina, N. Marintsova, A. Karkhut, I. Kravchenko, V. Novikov, A. Khairulin, Acta Chim. Slov. 67, 934-939 (2020)

130. I.A. Khodja, H. Boulebd, C. Bensouici, A. Belfaitah, J. Mol. Struct. 1218, 128527 (2020)

131. T.Y. Li, T. Meyer, R. Meerheim, M. Höppner, C. Körner, K. Vandewal, O. Zeika, K. Leo, J. Mater. Chem. A. 5, 10696-10703 (2017)

132. J. Xu, C. Mou, T. Zhu, B.A. Song, Y.R. Chi, Org. Lett. 16, 32723275 (2014)

133. N. Zhao, G.O. Lloyd, Chem. Commun. 48, 3070-3072 (2012)

134. L. Cai, K. Zhang, S. Chen, R.J. Lepage, K.N. Houk, E.H. Krenske, O. Kwon, J. Am. Chem. Soc. 141, 9537-9542 (2019)

135. H. Huang, D. Huang, M. Li, Q. Yao, R. Tian, S. Long, J. Fan, X. Peng, Dyes Pigm. 177, 108284 (2020)

136. V.V. Avdeeva, G.A. Buzanov, L.V. Goeva, A.V. Gerasimenko, E.A. Malinina, N.T. Kuznetsov, Inorg. Chim. Acta. 493, 38-42 (2019)

137. C. Liao, X. Li, K. Yao, Z. Yuan, Q. Chi, Z. Zhang, ACS Sustain. Chem. Eng. 7, 13646-13654 (2019)
138. D.V. Geetha, F.H. Al-Ostoot, Y.H. Mohammed, M.A. Sridhar, S.A. Khanum, N.K. Lokanath, J. Mol. Struct. 1178, 384-393 (2019)

139. M. Shiri, M.A. Zolfigol, H.G. Kruger, Z. Tanbakouchian, Chem. Rev. 110, 2250-2293 (2010)

140. M.S. Hendy, A.A. Ali, L. Ahmed, R. Hossam, A. Mostafa, M.M. Elmazar, B.H. Naguib, Y.M. Attia, M.S. Ahmed, Eur. J. Med. Chem. 166, 281-290 (2019)

141. S. Lal, T.J. Snape, Curr. Med. Chem. 19, 4828-4837 (2012)

142. F.H. Al-Ostoot, D.V. Geetha, Y.H. Mohammed, P. Akhileshwari, M.A. Sridhar, S.A. Khanum, J. Mol. Struct. 1202, 127244 (2020)

143. Y. Shimazaki, T. Yajima, M. Takani, O. Yamauchi, Coord. Chem. Rev. 253, 479-492 (2009)

144. D. Kumar, S. Sharma, S. Kalra, G. Singh, V. Monga, B. Kumar, Curr. Drug Targ. 21, 864-891 (2020)

145. M. Shiri, Chem. Rev. 112, 3508-3549 (2012)

146. P.H. França, D.P. Barbosa, D.L. da Silva, E.A. Ribeiro, A.E. Santana, B.V. Santos, J.M. Barbosa-Filho, J.S. Quintans, R.S. Barreto, L.J. Quintans-Júnior, J.X. Araújo-Júnior, BioMed Res. Int. 2014, 1-12 (2014)

147. Y. Zhao, Mol. Plant. 5, 334-338 (2012)

148. Z. Bakherad, M. Safavi, A. Fassihi, H. Sadeghi-Aliabadi, M. Bakherad, H. Rastegar, J.B. Ghasemi, S. Sepehri, L. Saghaie, M. Mahdavi, Res. Chem. Intermed. 45, 2827-2854 (2019)

149. N.M. Cury, R.M. Capitao, R.D. de Almeida, L.L. Artico, J.R. Correa, E.F. dos Santos, J.A. Yunes, C.R. Correia, Eur. J. Med. Chem. 181, 111570 (2019)

150. Y. Ji, W. Yin, Y. Liang, L. Sun, Y. Yin, W. Zhang, Int. J. Mol. Sci. 21, 1579 (2020)

151. T.V. Sravanthi, S.L. Manju, Eur. J. Pharm. Sci. 91, 1 (2016)

152. I. Hdoufane, J. Stoycheva, A. Tadjer, D. Villemin, M. NajdoskaBogdanov, J. Bogdanov, D. Cherqaoui, J. Mol. Struct. 1193, 429-443 (2019)

153. J. Kaur, D. Utreja, N. Jain, S. Sharma, Curr. Org. Synth. 16, 17-37 (2019)

154. P. Konopelski, M. Ufnal, Curr. Drug Metab. 19, 883-890 (2018)

155. M.M. Valko, H. Morris, M.T. Cronin, Curr. Med. Chem. 12, 1161-1208 (2005)

156. Q.V. Vo, A. Mechler, J. Chem. Inf. Model. 60, 316-321 (2019)

157. K.N. Dhiraviam, S. Balasubramanian, S. Jayavel, Curr. Bioinf. 13, 157-169 (2018)

158. R. Cao, H. Islamoglu, G. Teskey, K. Gyurjian, R. Abrahem, O.K. Onajole, S. Lun, W. Bishai, A.P. Kozikowski, M.P. Fraix, A. Sathananthan, Int. Microbiol. 23, 161-170 (2020)

159. P.V. Thanikachalam, R.K. Maurya, V. Garg, V. Monga, Eur. J. Med. Chem. 180, 562-612 (2019)

160. S. Cacchi, G. Fabrizi, Chem. Rev. 105, 2873-2920 (2005)

161. E. Fischer, F. Jourdan, Springer, Berlin, Heidelberg (1924), pp. 437-441

162. S.M. Sandes, L. Heimfarth, R.G. Brito, P.L. Santos, D.N. Gouveia, A.M. Carvalho, J.S. Quintans, E.F. da Silva-Júnior, T.M. de Aquino, P.H. França, J.X. de Araújo-Júnior, Chem. Biol. Interact. 286, 1-10 (2018)

163. P.F. Lamie, W.A. Ali, V. Bazgier, L. Rárová, Eur. J. Med. Chem. 123, 803-813 (2016)

164. M. Demurtas, A. Baldisserotto, I. Lampronti, D. Moi, G. Balboni, S. Pacifico, S. Vertuani, S. Manfredini, V. Onnis, Bioorg. Chem. 85, 568-576 (2019)

165. A.M. El-Sharief, Y.A. Ammar, A. Belal, M.A. El-Sharief, Y.A. Mohamed, A.B. Mehany, G.A. Ali, A. Ragab, Bioorg. Chem. 85, 399-412 (2019)

166. A. Amuthavalli, B. Prakash, R. Thirugnanasampandan, M. Gogulramnath, G. Bhuvaneswari, R. Velmurugan, Synth. Commun. 50, 1176-1189 (2020)

167. Y. Huang, B. Zhang, J. Li, H. Liu, Y. Zhang, Z. Yang, W. Liu, Eur. J. Med. Chem. 180, 41-50 (2019) 
168. R.C. Mohs, N.H. Greig, Alzheim. Dement (N Y) 3, 651-657 (2017)

169. G.S. Perrott, D.F. Holland, Milbank Q. 83, 569 (2005)

170. K.K. Jha, S. Kumar, I. Tomer, R. Mishra, J. Pharm. Res. 5, 560566 (2012)

171. R. Dua, S. Shrivastava, S.K. Sonwane, S.K. Srivastava, Adv. Biol. Res. 5, 120-144 (2011)

172. S.M. Prajapati, K.D. Patel, R.H. Vekariya, S.N. Panchal, H.D. Patel, RSC Adv. 4, 24463-24476 (2014)

173. X.M. Chu, C. Wang, W. Liu, L.L. Liang, K.K. Gong, C.Y. Zhao, K.L. Sun, Eur. J. Med. Chem. 161, 101-117 (2019)

174. C. Verma, M.A. Quraishi, E.E. Ebenso, Surf. Interfaces. 21, $100634(2020)$

175. V.V. Kouznetsov, L.Y. Mendez, C.M. Gomez, Curr. Org. Chem. 9, 141-161 (2005)

176. S. Gogoi, K. Shekarrao, A. Duarah, T.C. Bora, S. Gogoi, R.C. Boruah, Steroids 77, 1438-1445 (2012)

177. C. Teja, F.R. Khan, Chem. Asi. J. 1, 1-7 (2020)

178. M.P. Ambatkar, P.B. Khedekar, J. Drug Deliv. Ther. 9, 782-788 (2019)

179. L.P. Guan, Q.H. Jin, G.R. Tian, K.Y. Chai, Z.S. Quan, J. Pharm. Pharm. Sci. 10, 254-262 (2007)

180. A. Amer, A. Deeb, W.I. El-Eraky, S.A. El Awdan, S. Mahgoub, Egypt. J. Chem. 30, 67-77 (2018)

181. S.A. Khan, A.M. Asiri, H.M. Basisi, M. Asad, M.E. Zayed, K. Sharma, M.Y. Wani, Bioorg. Chem. 88, 102968 (2019)
182. G.Z. Yang, J.K. Zhu, X.D. Yin, Y.F. Yan, Y.L. Wang, X.F. Shang, Y.Q. Liu, Z.M. Zhao, J.W. Peng, H. Liu, J. Agric. Food Chem. 67, 11340-11353 (2019)

183. S. Kapishnikov, T. Staals $\varnothing$, Y. Yang, J. Lee, A.J. Pérez-Berná, E. Pereiro, S. Werner, P. Guttmann, L. Leiserowitz, J. Als-Nielsen, Proc. Natl. Acad. Sci. 116, 22946-22952 (2019)

184. H.A. Khudhair, Int. J. Eng. Technol. 7, 53-56 (2018)

185. S.N. Pandeya, A. Tyagi, ChemInform. 3, 5361 (2012)

186. N.G. Grigor, A.V. Bayburtli, R.Z. Kuvatova, T.V. Semenova, S.V. Bubennov, G.Z. Raskildina, S.S. Zlotsky, B.I. Kutepov, Russ. Chem. Bull. 69, 525-528 (2020)

187. A.S. Prasad, A.G. Reddy, V.N. Tokala, K. Deepthi, T.B. Rao, M.B. Rao, Chem. Data Collect. 28, 100469 (2020)

188. M. Taha, S. Sultan, S. Imran, F. Rahim, K. Zaman, A. Wadood, A.U. Rehman, N. Uddin, K.M. Khan, Bioorg. Med. Chem. 27, 4081-4088 (2019)

189. T.K. Köprülü, S. Ökten, Ş Tekin, O. Çakmak, J. Biochem. Mol. Toxicol. 33, 22260 (2019)

190. K. Douadi, S. Chafaa, T. Douadi, M. Al-Noaimi, I. Kaabi, J. Mol. Struct. 1217, 128305 (2020)

191. R. Reddyrajula, U. Dalimba, ChemistrySelect. 4, 2685-2693 (2019) 